\title{
Study of Aryl Triazoles for Absolute Configuration Determination
}

\author{
Sara Tejera, Rosa L. Dorta, and Jesús T. Vázquez* \\ Instituto Universitario de Bio-Orgánica “Antonio González”, Departamento de Química Orgánica, \\ Universidad de La Laguna, 38206 La Laguna, Tenerife, Spain \\ Tel.:+34-922318581; fax: +34-922318571; e-mail: jtruvaz@ull.es
}

\begin{abstract}
A variety of chiral mono- and di-1,4-disubstituted 1,2,3-triazoles were synthesized by CuAAC 'click chemistry' as model compounds and their spectroscopic properties characterized. The UV and CD study of these compounds showed that 4-substituted aryl triazoles give rise to moderate exciton CD curves, under either homo- or hetero-coupling. The direction of the electric transition moment of the non-symmetric chromophores was determined by conformational analysis and supported by NMR data. The signs of the Cotton effects of the CD spectra were in complete agreement with the determined directions of the electric transition moments of the chromophores. Therefore, 4-substituted aryl triazoles can be used for the determination of the absolute configuration of organic compounds. In addition, the 4-(4-bromo-phenyl)-1,2,3-triazole allows red-shifted chromophores to be obtained via Suzuki reactions, thus avoiding overlap with the substrate absorptions.@ 2019 Elsevier Science. All rights reserved
\end{abstract}

\section{Introduction}

The 1,3-dipolar cycloaddition reaction between azides and alkynes catalyzed by $\mathrm{Cu}^{+}$salts $(\mathrm{CuAAC})$ to obtain $1,2,3-$ triazoles, developed independently by Sharpless ${ }^{1}$ and Meldal, ${ }^{2}$ has led to a huge amount of scientific articles as a consequence of its wide range of applications. ${ }^{3}$ Moreover, this 'click' reaction ${ }^{4}$ leads to high yields, mild reaction conditions, and excellent selectivity, being compatible with many functional groups.

Triazoles have been also studied because of their broad range of biological activities, ${ }^{5}$ including anti-inflammatory, antimicrobial, antitumoral, antiplatelet, antiviral, and antifungal properties, as well as for being glycosidase ${ }^{6}$ and glycogen phosphorylase ${ }^{7}$ inhibitors.

The 1,2,3-triazole ring has been used as a linker to join two molecules or macromolecules, and many interesting entities have been synthesized. It is furthermore considered a nonclassical bioisostere of an amide (Fig. 1). ${ }^{8}$ When several triazolyl units are present in a molecule together with other functional groups they can interact through intra- and intermolecular interactions. As a result interesting conformations or supramolecular conformations may be established. ${ }^{8,9}$

Circular Dichroism (CD) is a very effective technique for both conformational and configurational analysis of organic molecules. In particular the exciton chirality method ${ }^{10}$ developed by Harada and Nakanishi is a powerful tool. Due to the fact that compounds with a triazole ring have a great chemical and biological impact, as well as very interesting conformational and supramolecular properties, ${ }^{9}$ we decided to test triazolyl derivatives as chromophores in CD studies. So, a variety of compounds having different alkyl and aryl substituents in the triazole ring was first synthesized, by using the 1,3-dipolar cycloaddition reaction between glycosyl azides and alkynes catalyzed by $\mathrm{Cu}+$ salts (CuAAC), and then analyzed by UV and CD spectroscopy. In addition, a large set of di-triazolyl derivatives with different molecular structures were prepared and measured by UV/CD. The results show that 4-substituted aryl triazoles are chromophores, which can be used for absolute configuration determination by $\mathrm{CD}$, as they give rise to exciton-coupled CD curves.

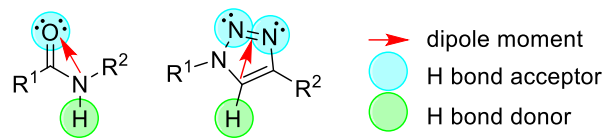

Figure 1. Structural feature comparison of 1,4-disubstituted triazole and trans-amide.

\section{Results and discussion}

\subsection{Synthesis.}

A wide set of mono chiral 1,4-disubstituted triazoles were synthesized using the 1,3-dipolar cycloaddition reaction 
between glycosyl azides and alkynes, catalyzed by $\mathrm{Cu}+$ salts (CuAAC) (Schemes 1 and 2).

The 2,3,4,6-tetra- $O$-acetyl- $\beta$-D-glucopyranosyl azide (1) was prepared with an almost quantitative yield from the corresponding per- $O$-acetylated glucopyranoside by means of trimethylsilyl azide in $\mathrm{CH}_{2} \mathrm{Cl}_{2}$, catalyzed by $\mathrm{SnCl}_{4} \cdot{ }^{11}$ The $\alpha$-glucopyranosyl azide $\mathbf{3}$ was obtained in two steps: (i) chlorination of the per- $O$-acetylated $\beta$-D-glucopyranoside with phosphorus pentachloride and catalyzed by boron trifluoride etherate, ${ }^{12}$ and then (ii) with trimethylsilyl azide and tetrabutylammonium fluoride in THF. ${ }^{13}$

The 1- $\beta$-D-glucosyl-4-substituted triazoles $\mathbf{2 a}-\mathbf{2} \mathbf{g}$ and their $\alpha$-anomers $\mathbf{4 a}, \mathbf{4 f}$, and $\mathbf{4 g}$ (Scheme 1) were obtained from the corresponding alkynes, copper (II) sulfate, and sodium ascorbate, in $\mathrm{H}_{2} \mathrm{O} / t-\mathrm{BuOH}(1: 1)$ or $\mathrm{H}_{2} \mathrm{O}$ at $70{ }^{\circ} \mathrm{C}$ overnight. $^{6,7}$ Compound 5a was obtained in $86 \%$ yield from $\mathbf{2 a}$ and sodium methoxide in $\mathrm{CH}_{2} \mathrm{Cl}_{2} / \mathrm{MeOH}$. Following this, the 1-mannopyranosyl-4-(4-bromophenyl)triazole 7f (Scheme 2) was prepared from its corresponding azide 6, following the general procedure for the 1,3-dipolar cycloaddition (CuAAC).
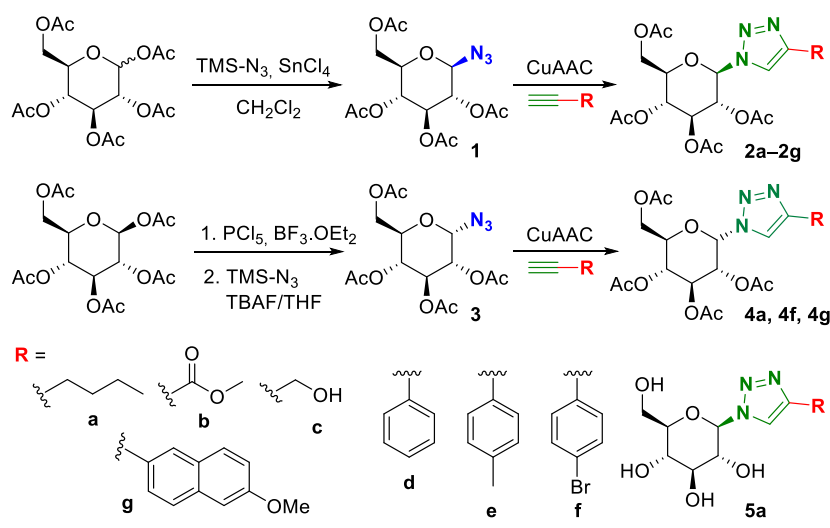

Scheme 1. Synthesis of 4-substituted-1-glucopyranosyl triazoles.

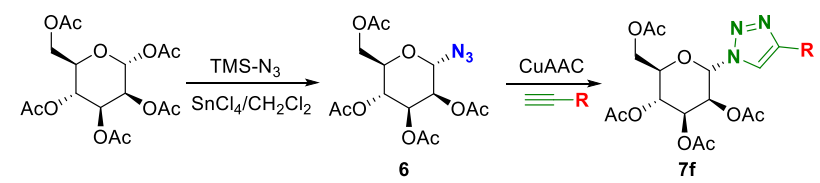

Scheme 2. Synthesis of the 4-substituted-1-mannopyranosyl triazole 7f.

In addition, several series of new di-triazolyl glycopyranosides were synthesized. Thus, the 1,2-di-(4substituted triazolyl)- $\beta$-D-glucopyranosides 11a-11g and their corresponding $\alpha$-anomers 12a-12g (Scheme 3 ) were prepared from the 1,2-diazides $\mathbf{9}$ and $\mathbf{1 0}$, respectively, following the general procedures for the 1,3-dipolar cycloaddition (CuAAC). ${ }^{6,7,14,15}$ The 1,2-diazides 9 and $\mathbf{1 0}^{16}$ were obtained in $61 \%$ yields in two steps from 2-amino-2deoxy-D-glucose hydrochloride by: (i) treatment with $\mathrm{TFN}_{3}$ in $\mathrm{H}_{2} \mathrm{O} / \mathrm{Et}_{3} \mathrm{~N}$ and then with acetic anhydride in $\mathrm{Py}$ to give rise to the per- $O$-acetylated glucopyranosyl azide $\mathbf{8},{ }^{17,18}$ and (ii) introduction of the second azide functional group at the anomeric position with trimethylsilyl azide and tin tetrachloride in $\mathrm{CH}_{2} \mathrm{Cl}_{2}$. ${ }^{11}$
Compounds $13 f$ and $14 f$ were obtained in good yields by treatment of compounds $\mathbf{1 1 f}$ and $\mathbf{1 2 f}$ respectively with sodium methoxide in $\mathrm{CH}_{2} \mathrm{Cl}_{2} / \mathrm{MeOH}$ (Scheme 3).

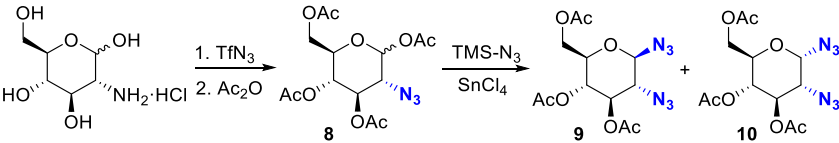

$$
\begin{aligned}
& 9 \frac{\bar{\equiv}}{\overline{11 a-11 g\left(R^{1}=A c\right)}}
\end{aligned}
$$

Scheme 3. Synthesis of 1,2-di-(4-substituted triazolyl) gluco-pyranosides.

Other model compounds were also tested. Thus, the 1,2bis(4-(4-bromophenyl)-triazol-1-yl)-cyclohexane (16f) was obtained in $81 \%$ yield from its diazide $\mathbf{1 5},{ }^{16}$ derived from the commercially available $(1 R, 2 R)-(-)-1,2-$ diaminocyclohexane, following the diazo transfer reaction (Scheme 4). ${ }^{17,18}$

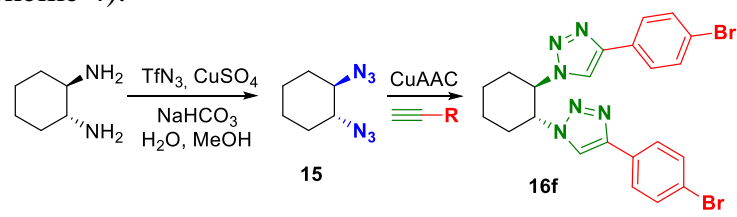

Scheme 4. Synthesis of the 1,2-bis(4-(4-bromophenyl)-triazol-1-yl)cyclohexane (16f)

The presence of a bromo atom in para position with respect to the triazolyl group allows expanding the chromophore with another phenyl group. So, a Suzuki coupling (Scheme 5) using microwave ${ }^{19}$ of this triazole 16f in DMSO and 4hydroxy-phenylboronic acid, $\mathrm{Na}_{2} \mathrm{CO}_{3}$, and $\mathrm{Pd}(\mathrm{OAc})_{2} / \mathrm{PPh}_{3}$ led to the desired $(1 R, 2 R)$-1,2-bis(4-(biphenyl-4-ol)-triazol$1-y l) c y c l o h e x a n e ~ 17$ in $74 \%$ yield.

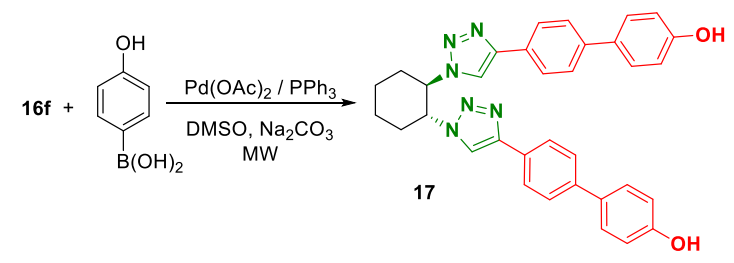

Scheme 5. Derivatization to a red-shifted triazolyl chromophore $\mathbf{1 7}$.

Compounds containing two types of chromophores were also prepared. ${ }^{10,20}$ Thus, compounds $20 f$ and 21f, having the a $p$-bromophenyl triazole and a $p$-bromo benzoate were obtained in high yields from their corresponding $p$ bromobenzoyl azides $\mathbf{2 8}$ and $\mathbf{2 9}$, which were obtained in $73 \%$ yield $(\beta: \alpha=1.5: 1)$ from the 2-azide-2-deoxy glucopyranoside $\mathbf{8}$ in two steps (Scheme 6). 


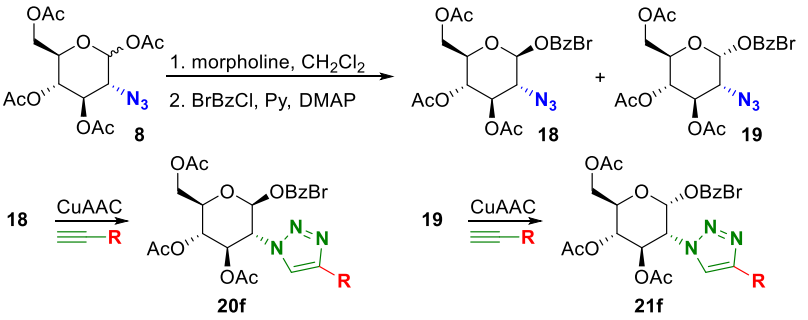

Scheme 6. Synthesis of the bi-chromophoric compounds $20 f$ and $21 f$.

2.2. Characterization and NMR spectroscopic analysis.

All these compounds were characterized on the basis of their one- $\left({ }^{1} \mathrm{H}\right.$ and $\left.{ }^{13} \mathrm{C}\right)$ and two-dimensional NMR spectroscopy, ES or EI mass spectrometry data, and elemental analysis. Since all model compounds contain one or two CD exciton-coupled chromophores, these compounds were also characterized by UV and CD spectroscopy (see Tables 1 and 2).

Scheme 7 shows some characteristic NMR data for the mono and di-triazolyl glucopyranosides, for both the alpha and beta anomers. Thus, a singlet between 7.0-8.3 ppm was observed for the proton of the triazole ring, and large positive differences between the chemical shift of the triazolyl $\mathrm{C} 4$ and $\mathrm{C} 5$ signals $\left(\Delta \delta_{\mathrm{C} 4-\mathrm{C} 5}=23-31\right.$ units $)$ confirming the 1,4 regioselectivity of the 1,3-cycloaddition reaction. $^{21}$ The anomeric configuration was assigned in each case by analyzing the coupling constant between $\mathrm{H} 1$ and $\mathrm{H} 2$ protons (Scheme 7 and Tables I and II). The chemical shifts of the $\mathrm{H} 3$ and $\mathrm{H} 5$ protons supported the assigned configuration; the alpha anomer signals being deshielded compared to those of the beta form, especially those of $\mathrm{H} 3$.

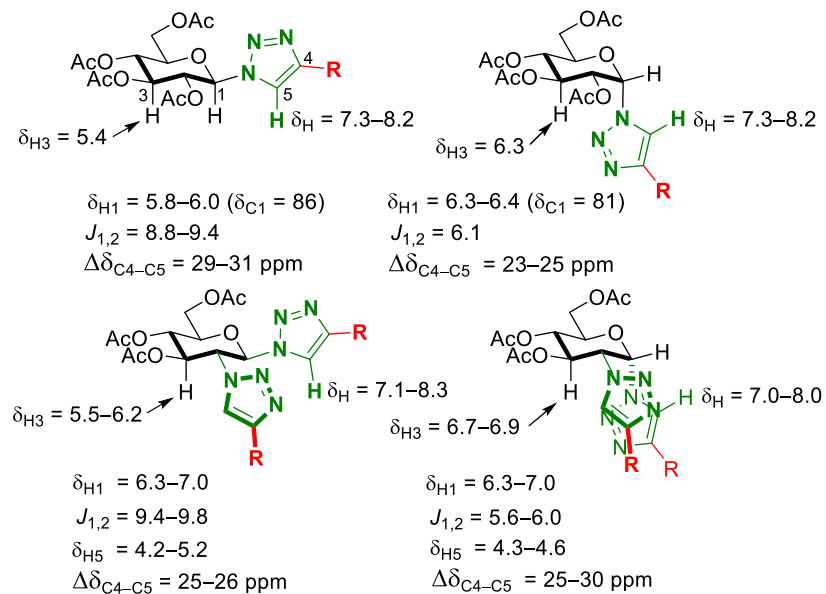

Scheme 7. Some characteristic NMR data of mono- and di-triazolyl glucopyranosides 2a-2g, 4a, 4f, 4g, 11a-11g and 12a-12g.

Compounds $16 \mathbf{f}$ and $\mathbf{1 7}$ showed spectroscopic data in total agreement with their chemical structures as well as the bichromophoric glucopyranosides $20 f$ and 21f. Compound $20 f$ showed a singlet at 7.84, corresponding to the triazolyl proton whereas for $\mathbf{2 1 f}$ it was at $7.79 \mathrm{ppm}$. The anomeric configuration was directly determined on the basis of the expected $J_{\mathrm{H} 1, \mathrm{H} 2}$ coupling constants, $8.7 \mathrm{~Hz}$ for the beta anomer and $3.3 \mathrm{~Hz}$ for the alpha one. In addition, a signal around $163 \mathrm{ppm}$ in the ${ }^{13} \mathrm{C}$ NMR spectra of these compounds confirmed the presence of the $p$-bromobenzoyl group.

\subsection{Study of Aryl Triazoles for Absolute Configuration Determination: UV and CD Spectroscopic Analysis.}

Different alkynes were used in the 1,3-cycloaddition reaction (CuAAC) to obtain a wide set of mono 1,4disubstituted-1,2,3-triazoles (Schemes 1 and 2, and Table 1). The substituent attached at position 1 of the triazole ring was a glycosyl substituent of either glucose or mannose, with an alpha or beta anomeric configuration, while that at position 4 was an alkyl, a methoxycarbonyl, a hydroxymethyl, a phenyl or a naphthyl group.

To test whether these triazoles can be considered as chromophores to be applied using the exciton chirality method, their maximum UV wavelength and their corresponding molar extinction coefficient ( $\varepsilon$ value) were determined (Table 1). The aromatic character of the triazole ring was early determined by ultraviolet spectra comparison between the 4-phenyl and biphenyl triazoles, since both spectra exhibit a maximum at $245 \mathrm{~nm}$ in $95 \%$ ethanol, ${ }^{22}$ and also by semi-empirical calculations. ${ }^{8 b}$

Only the 4-aryl or 4-naphthyl substituents attached to the triazole ring give rise to large $\varepsilon$ values higher than 15000 and suitable wavelengths for UV and CD measurements, meaning that the triazole ring is a weak chromophore per se. This can be deduced by comparing compound $2 \mathbf{a}(\mathrm{R}=$ alkyl) with $\mathbf{2 e}$ and $\mathbf{2 f}(\mathrm{R}=4$-aryls) (Table 1 and Figure 2$)$. To increase the extinction coefficient and establish the direction of the electric transition moment in the chromophore, two other phenyl derivatives with another substituent in para position were studied and compared with the non-substituted 4-phenyl triazole $\mathbf{2 d}$. The introduction of a methyl group or a bromine atom results in bathochromic and hyperchromic effects as would be expected, from $243 \mathrm{~nm}$ for compound 2d ( $\varepsilon$ 15000), to 248 $\mathrm{nm}$ for compound $2 \mathrm{e}$ ( $\varepsilon$ 18800), and to $254 \mathrm{~nm}$ for compound 2f ( $\varepsilon$ 25000) (Figure 2). The UV spectra of the 4-(6-methoxynaphthyl-2-yl) triazoles $\mathbf{2 g}$ and $\mathbf{4 g}$ show up to five absorption bands. The main one around $245 \mathrm{~nm}$ is redshifted from $220 \mathrm{~nm}\left({ }^{1} \mathrm{~B}_{\mathrm{b}}\right.$ band of naphthalene) due to the strong interaction with the triazole ring.

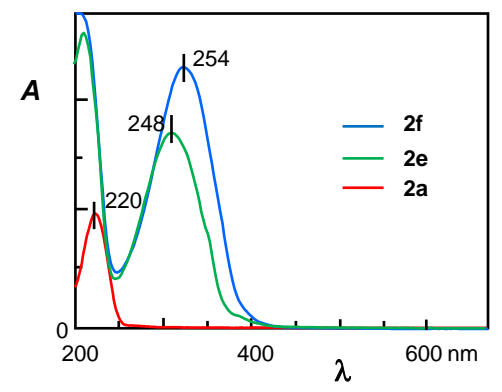

Figure 2. UV spectra of some triazolyl derivatives: $2 \mathbf{a}, \mathbf{2 e}$, and $\mathbf{2 f}$ $\left(\mathrm{CH}_{3} \mathrm{CN}\right)$. 
Table 1.

Some UV and DC data $\left(\mathrm{CH}_{3} \mathrm{CN}\right)$ and $J_{1,2}$ coupling constants $\left(\mathrm{CDCl}_{3}\right)$ of triazolyl glycopyranosides.

\begin{tabular}{cccccc}
\hline$\#$ & $\begin{array}{c}\text { Anom. } \\
\text { Conf. }\end{array}$ & $\begin{array}{c}\text { UV } \\
\lambda_{\max } \\
(\mathrm{nm})\end{array}$ & $\varepsilon$ value & $\begin{array}{c}\mathrm{CD} \lambda_{\text {ext }}(\mathrm{nm}) \\
(\Delta \varepsilon)\end{array}$ & $\begin{array}{c}J_{\mathrm{H} 1 \mathrm{H} 2} \\
(\mathrm{~Hz})\end{array}$ \\
\hline $\mathbf{2 a}$ & $\beta$ & 220 & 3940 & $220(-1.1)$ & 9.0 \\
\hline $\mathbf{2 b}$ & $\beta$ & 211 & 11700 & $219(-3.4)$ & 9.0 \\
\hline $\mathbf{2 c}$ & $\beta$ & 218 & 3900 & $220(-1.3)$ & 8.8 \\
\hline $\mathbf{2 d}$ & $\beta$ & 243 & 15000 & $230(-3.3)$ & 9.4 \\
\hline $\mathbf{2 e}$ & $\beta$ & 248 & 18800 & $244(-3.8)$ & 9.4 \\
\hline $\mathbf{2 f}$ & $\beta$ & 254 & 25500 & $247(-4.3)$ & 9.2 \\
\hline $\mathbf{2 g}$ & $\beta$ & 245 & 49400 & $245(-6.4)$ & 9.4 \\
\hline $\mathbf{4 a}$ & $\alpha$ & 221 & 3940 & $b r 217(-0.5)$ & 6.1 \\
\hline $\mathbf{4 f}$ & $\alpha$ & 254 & 25500 & $252(+2.9)$ & 6.1 \\
\hline $\mathbf{4 g}$ & $\alpha$ & 245 & 49400 & $245(+3.3)$ & 6.1 \\
\hline $\mathbf{5 a} \mathbf{a}^{[\mathrm{a}]}$ & $\beta$ & 221 & 1900 & $213(-1.2)$ & 9.2 \\
\hline $\mathbf{7 f}$ & $\alpha$ & 253 & 25500 & $252(+2.2)$ & 2.7 \\
\hline
\end{tabular}

[a] $\mathrm{MeOH}$

CD of all these mono chromophoric compounds exhibited a weak positive or negative Cotton effect at the wavelength of their absorption maxima (normal CD), in addition to the broad and very weak positive Cotton effect around $290 \mathrm{~nm}$ of the acetyl groups (Figure 3). Compound 5a without the acetyl groups showed only the Cotton effect corresponding to the triazole ring. The sign of the former Cotton effect depends on the anomeric configuration of the glucopyranosyl ring to which the triazole is attached. Thus, all compounds exhibiting the $\beta$ anomeric configuration exhibited a negative Cotton effect, while those with the $\alpha$ configuration were positive in sign, except compound $\mathbf{4 a}$, which exhibited a very weak negative Cotton effect $(\Delta \varepsilon-0.5)$.

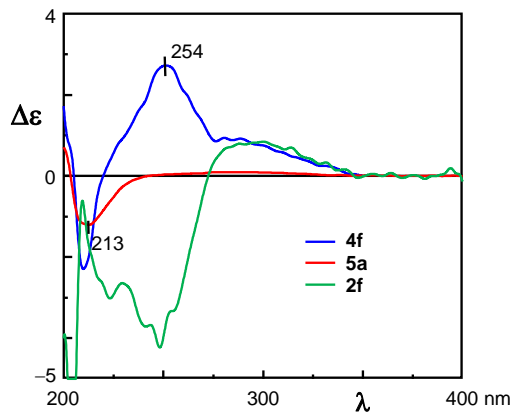

Figure 3. $\mathrm{CD}$ spectra of compounds $\mathbf{2 f}, \mathbf{4 f}\left(\mathrm{CH}_{3} \mathrm{CN}\right)$ and $\mathbf{5 a}(\mathrm{MeOH})$.

The CD exciton chirality method is based on the coupling of the transition moments of two or more chromophores within a chiral molecule through space. In addition, these chromophores must meet two conditions, to have a large extinction coefficient ( $\varepsilon$ value) and a well-known direction of the electric transition moment, i.e., the transition polarization. The exciton coupling between them gives rise to a split CD curve, namely a spectrum with two Cotton effects of opposite signs. The sign of the split CD curve is determined by the chirality of the chromophore transition moments.

Similarly to the mono-triazoles, a wide set of di-triazoles (Schemes 3-5) were thus synthesized and analyzed. CD analysis of compounds 11a-11g (with a beta anomeric configuration) exhibited negative first/positive second exciton Cotton effects (Table 2). Figure 4 shows the exciton split CD curve of the di-triazole $11 f(262 \mathrm{~nm},-11.3$ / $240 \mathrm{~nm},+3.5$ ) compare with that of its corresponding mono-triazole 2f, which exhibits a normal Cotton effect at the wavelength of the UV $\lambda_{\max }$. Furthermore, the intensity of the first Cotton effects increasing from 11a (228 $\mathrm{nm},-1.9)$ to $\mathbf{1 1 g}(255 \mathrm{~nm},-29.3)$ are in agreement with the $\varepsilon$ value. However, the observed $\mathrm{CD}$ exciton couplets are very weak, although when it has a proper substituent at 4 position, such as an aryl or naphthyl group, moderate intensity CD spectra of the exciton couplets are obtained (Fig. 4, Table 2).

Table 2.

Some UV and DC data $\left(\mathrm{CH}_{3} \mathrm{CN}\right)$ and $J_{1,2}$ coupling constants $\left(\mathrm{CDCl}_{3}\right)$ of 1,2-di-triazolyl glycopyranosides.

\begin{tabular}{ccccccc}
\hline$\#$ & $\begin{array}{c}\text { Anom. } \\
\text { Conf. }\end{array}$ & $\begin{array}{c}\lambda_{\text {max }} \\
(\mathrm{nm})\end{array}$ & $\begin{array}{c}\varepsilon \\
\text { value }\end{array}$ & $\begin{array}{c}\mathrm{CD} \\
\lambda_{\text {ext }}(\mathrm{nm})(\Delta \varepsilon)\end{array}$ & $\begin{array}{c}A \\
\text { value }\end{array}$ & $\begin{array}{c}J_{\mathrm{H} 1 \mathrm{H} 2} \\
(\mathrm{~Hz})\end{array}$ \\
\hline $\mathbf{1 1 a}$ & $\beta$ & 220 & 7400 & $\begin{array}{c}212(+2.0) \\
228(-1.9)\end{array}$ & -3.9 & 9.6 \\
\hline $\mathbf{1 1 b}$ & $\beta$ & 211 & 20400 & $216(-4.0)$ & -4.0 & 9.4 \\
\hline $\mathbf{1 1 e}$ & $\beta$ & 248 & 34600 & $\begin{array}{c}235(+2.8) \\
257(-8.3)\end{array}$ & -11.1 & 9.5 \\
\hline $\mathbf{1 1 f}$ & $\beta$ & 252 & 48000 & $\begin{array}{c}240(+3.5) \\
262(-11.3)\end{array}$ & -14.8 & 9.8 \\
\hline $\mathbf{1 1 g}$ & $\beta$ & 246 & 96000 & $\begin{array}{c}238(+16.7) \\
255(-29.3)\end{array}$ & -46.0 & 9.5 \\
\hline $\mathbf{1 2 a}$ & $\alpha$ & 222 & 7400 & $225(+4.5)$ & +4.5 & 6.0 \\
\hline $\mathbf{1 2 b}$ & $\alpha$ & 211 & 20400 & $\begin{array}{c}211(+4.2) \\
226(-1.4)\end{array}$ & -5.6 & 6.0 \\
\hline $\mathbf{1 2 e}$ & $\alpha$ & 246 & 34600 & $\begin{array}{c}236(+6.2) \\
255(-11.2)\end{array}$ & -17.4 & 5.9 \\
\hline $\mathbf{1 2 f}$ & $\alpha$ & 252 & 48000 & $\begin{array}{c}241(+9.3) \\
260(-14.5)\end{array}$ & -23.8 & 5.9 \\
\hline $\mathbf{1 2 g}$ & $\alpha$ & 245 & 96000 & $\begin{array}{c}234(+53.8) \\
255(-69.2)\end{array}$ & - & 5.6 \\
\hline $\mathbf{1 3 f}$ & $\beta$ & 252 & 48000 & $\begin{array}{c}242(+4.7) \\
263(-18.1)\end{array}$ & -22.8 & 9.8 \\
\hline $\mathbf{1 4 f}$ & $\alpha$ & 253 & 48000 & $\begin{array}{c}242(+8.9) \\
261(-26.5)\end{array}$ & -35.4 & 5.7 \\
\hline
\end{tabular}

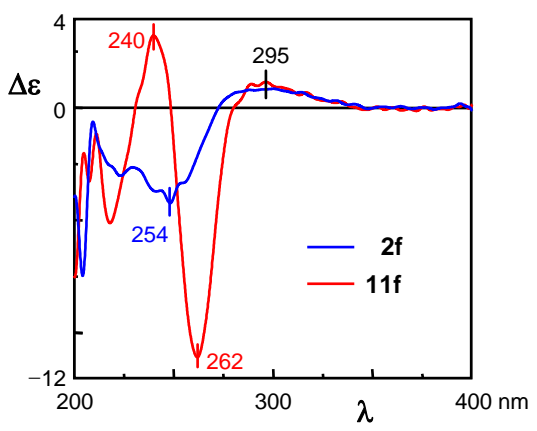

Figure 4. $\mathrm{CD}$ spectra of compounds $2 \mathbf{f}$ and $\mathbf{1 1 f}\left(\mathrm{CH}_{3} \mathrm{CN}\right)$ 
The equatorial dispositions of the triazolyl groups were confirmed by analyzing the $J_{\mathrm{H} 1, \mathrm{H} 2}$ coupling constant value, around $9.6 \mathrm{~Hz}$, in agreement with a ${ }^{4} \mathrm{C}_{1}$ chair conformation for the pyranoside ring.

The significance of the negative sign of these CD spectra is not immediately obvious. Firstly, the sign of the CD exciton couplet derives from the spatial interaction between the ${ }^{1} \mathrm{~L}_{\mathrm{a}}$ electric transition dipole moments of the 4-aryl triazoles, which can reasonably be assumed to be directed along the phenyl triazole bond, and not by the simple consideration of the dihedral angle $\mathrm{N} 1-\mathrm{C} 1-\mathrm{C} 2-\mathrm{N} 2$. Secondly, each 4-phenyl triazole chromophore can adopt different orientations to the chiral scaffold by rotating the $\mathrm{N}-\mathrm{C}$ bond (rotamerism) and consequently changing the direction of the transition dipole moment.

Molecular mechanics and semi-empirical calculations (PC Model and MOPAC) $)^{23}$ for compound 11f show there are several rotamers (Table 3 and Scheme 8 ). The most stable (rotamer F) and the third in stability (rotamer C) have a negative dihedral angle between their corresponding transition dipole moments, which explains the observed negative $\mathrm{CD}$ sign. The positive corresponding dihedral angle of $\mathrm{C}$ and the other rotamers explains the smaller $\mathrm{CD}$ couplet amplitude of ca. 15 delta epsilon exhibited for 11f, compared to the classical $p$-bromobenzoate of ca. 50 for a 1,2-trans-disubstituted system. ${ }^{10 a}$

Table 3.

Relative energy and dihedral angle between ${ }^{1} \mathrm{~L}_{\mathrm{a}}$ transition dipole moments for the conformers of the 1,2-di-triazolyl glucopyranoside 11f (MOPAC).

\begin{tabular}{ccc}
\hline Conformer & $\Delta \Delta \mathrm{H} \mathrm{Kcal} / \mathrm{mol}$ & $\begin{array}{c}\text { Dihedral angle } \\
\text { between }{ }^{1} \mathrm{~L}_{\mathrm{a}}\end{array}$ \\
$\mathrm{A}$ & 2.14 & +26.4 \\
$\mathrm{~B}$ & 2.20 & +25.5 \\
$\mathrm{C}$ & 0.56 & -65.5 \\
$\mathrm{D}$ & 3.42 & -17.1 \\
$\mathrm{E}$ & 0.20 & +28.4 \\
$\mathrm{~F}$ & 0.00 & -27.2 \\
\hline
\end{tabular}

For compounds $\mathbf{1 2 a}-\mathbf{1 2 g}$, with an alpha anomeric configuration, only those having an aromatic substituent at position 4 of the triazole ring showed clear split CD curves. These compounds should exhibit CD spectra of opposite sign to the beta anomers, however they not only retain the same sign observed for the $\beta$-anomers but are also at higher intensities. This result is independent of the presence of acetyl groups in the molecules since the unprotected 1,2bis-(4-(4-bromophenyl)-triazolyl)-pyranosides, compounds 13f and 14f (Scheme 3), displayed similar spectra to the corresponding $O$-acetyl glucopyranosides, although with slightly higher intensities.

Analysis of $J_{\mathrm{H} 1, \mathrm{H} 2}$ for some reported ${ }^{6,24}$ triazole derivatives (with alpha anomeric configurations) shows values around $6.0 \mathrm{~Hz}$, as occurred with our model compounds $12 \mathbf{a}-\mathbf{1 2 g}$. Furthermore, the strong deshielding of H5 and especially of $\mathrm{H} 3$ in ${ }^{1} \mathrm{H}$ NMR confirms the axial orientation of the triazole ring at the anomeric position as well as its conformational preference to locate the nitrogen atoms towards the inside of the pyranoside ring, therefore reducing the number of rotamers (Scheme 9). A previous X-ray analysis ${ }^{6,25}$ of an $\alpha$ triazolyl compound showed this preferred disposition of the triazolyl group at the anomeric position.
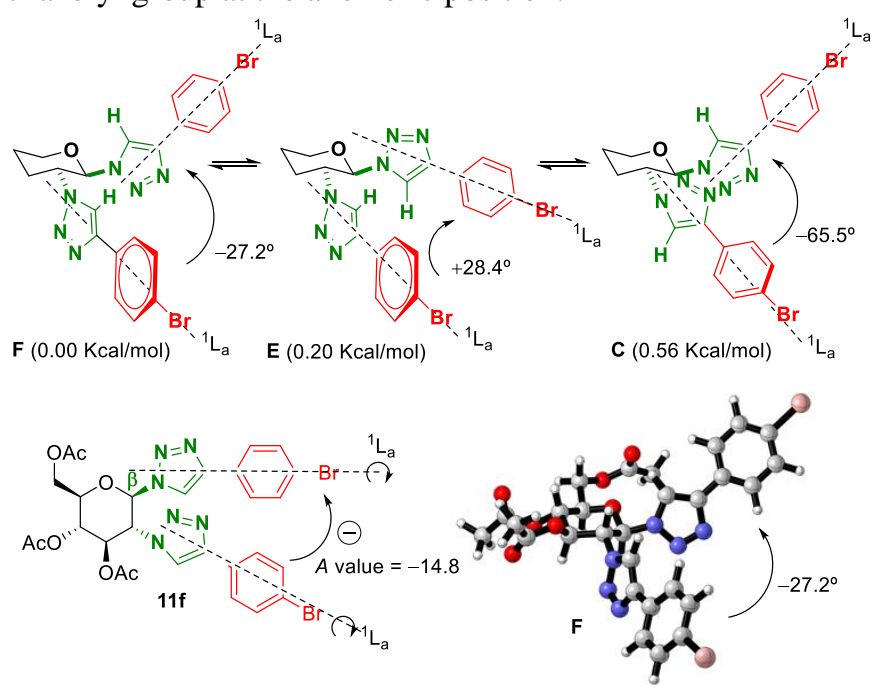

Scheme 8. The three lowest energy conformations of the $\beta$ glucopyranoside $11 \mathbf{f}$ (MOPAC).

Conformational analysis ${ }^{23}$ of compound $\mathbf{1 2 f}$ showed the existence of only one rotamer with less than $3 \mathrm{kcal} / \mathrm{mol}$ respect to the others. Scheme 9 shows some spectroscopic NMR data in complete agreement with this conformation. The negative dihedral angle $(\phi=-28.0)$ between its electric transition moments is in total agreement with the observed negative CD couplet $(A=-23.8)$.
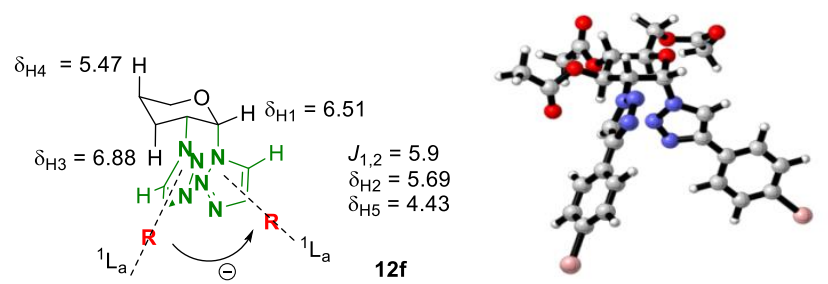

Scheme 9. The most stable rotamer for the $\alpha$-glucopyranoside $\mathbf{1 2 f}$ (MOPAC) and some spectroscopic data.

The 1,2-bis(4-(4-bromophenyl)-triazol-1-yl)-cyclohexane (16f), having both chromophores in equatorial disposition, showed a bisignate CD spectrum centered at the $\lambda_{\max } 252$ ( $\varepsilon$ 48000), namely a negative first Cotton effect at $263 \mathrm{~nm}$ $(-20.9)$ and a positive second Cotton effect at $241 \mathrm{~nm}$ (+4.1) (Figure 5). Furthermore, its derivative 17 showed a significant bathochromic effect in UV up to $285 \mathrm{~nm}(\varepsilon$ 70000) and a negative first Cotton effect at $298(-19.9)$ in CD. Although the second exciton Cotton effect was not observed in this latter case, ${ }^{10 a}$ the position and intensity of the former confirms the exciton coupling. 


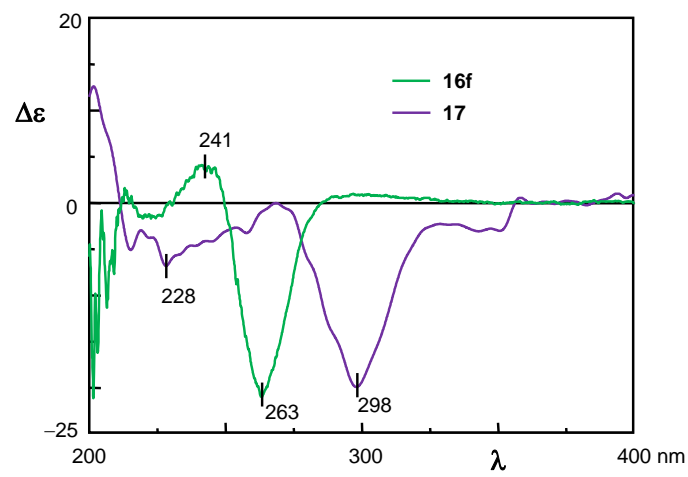

Figure 5. $\mathrm{CD}$ spectra of compounds $\mathbf{1 6 f}$ and $\mathbf{1 7}\left(\mathrm{CH}_{3} \mathrm{CN}\right)$.

In the case of $\beta$-glucopyranosides 11a-11g and 13f, the two aryl-triazolyl chromophores have equatorial configurations and exhibited a negative $\mathrm{CD}$ couplet. Similarly, the model compounds $\mathbf{1 6 f}$ and $\mathbf{1 7}$, also showed negative split CD curves (Scheme 10), having the same absolute configuration as the above. Once again, considering that the transition dipole moment of the ${ }^{1} \mathrm{~L}_{\mathrm{a}}$ band of the 4-aryl-triazole is directed along the long axis, the resulting dihedral angle between these transition moments is in accordance with the observed CD spectra. Thus, the 4-(biphenyl-4-ol)-1,2,3-triazolyl chromophore could be taken into account as a red-shifted chromophore for compounds having overlapping electronic transitions at shorter wavelengths. ${ }^{26}$

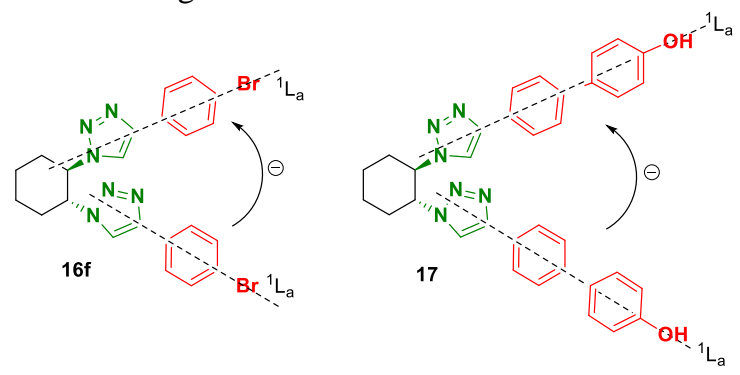

Scheme 10. Negative chirality between the ${ }^{1} L_{a}$ band transitions of the aryl-triazolyl chromophores of compound $\mathbf{1 6 f}$ and $\mathbf{1 7}$.

Finally, to test the behavior of the p-bromophenyl triazole under a hetero-exciton coupling interaction, ${ }^{10,20}$ two compounds 20f and 21f (Scheme 6) with two chromophores absorbing at different $\lambda_{\max }$, constituting a bichromophoric system, were prepared and analyzed (Figure 6). They have this same chromophore in equatorial disposition and a $p$-bromo benzoate chromophore in equatorial or axial disposition. These compounds showed $\lambda_{\max }$ at the wavelength of the triazolyl chromophore (250 $\mathrm{nm}$ ), and split Cotton effects with signs in agreement with their chiralities (Scheme 11). Thus, compound 20f exhibited a negative first Cotton effect at $258(-21.5)$ and a positive second Cotton effect at $240 \mathrm{~nm}(+12.0)(A=$ -33.5), while compound 21f showed Cotton effects at 258 $(+30.9)$ and $239 \mathrm{~nm}(-11.4),(A=+42.3)$.

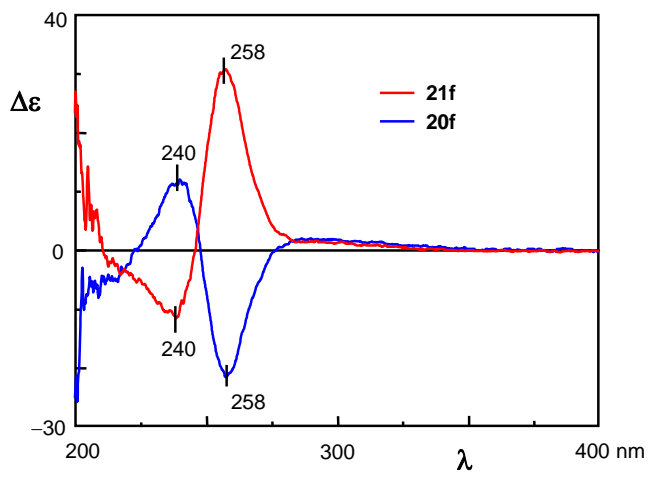

Figure 6. $\mathrm{CD}$ spectra of compounds $20 \mathrm{f}$ and $21 \mathrm{f}\left(\mathrm{CH}_{3} \mathrm{CN}\right)$.

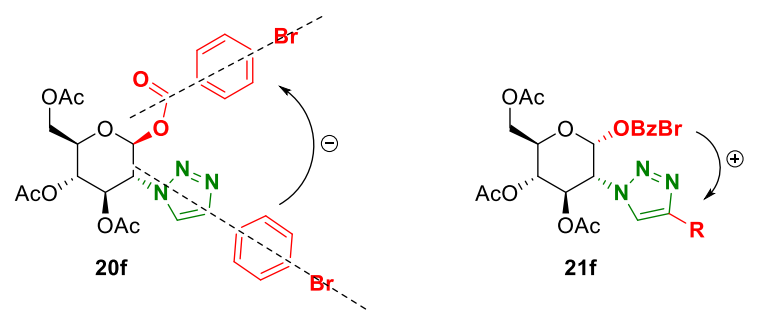

Scheme 11. Negative/positive chirality between the ${ }^{1} \mathrm{~L}_{\mathrm{a}}$ band transitions of the triazolyl chromophores of compound $20 \mathbf{f}$ and $21 \mathbf{f}$, respectively.

The signs of these CD couplets are in total agreement with the chirality of these molecules, and with the dihedral angle $\mathrm{O} 1-\mathrm{C} 1-\mathrm{C} 2-\mathrm{N} 2$. In addition, the observed amplitudes are greater than those observed for their analogous compounds with two 4-aryl triazoles, compounds $\mathbf{1 1 f}(A=-14.8)$ and $12 f(A=-23.8)$.

According to the exciton chirality method, the closer the $\lambda_{\max }$ of interacting chromophores, the more efficient the coupling. ${ }^{10}$ Thus, homo-interactions (between two chromophores absorbing at the same $\lambda_{\max }$ ) led to stronger split CD curves than hetero interactions (two chromophores absorbing at different $\lambda_{\max }$ ), the latter showing more complex but sometimes more useful CD spectra.

The higher amplitude of the split CD curves for these compounds with respect to those with two 4-aryl triazolyl chromophores may be explained by a reduction in the number of conformers, by substituting a 4-aryl triazole with a highly symmetric 4-bromobenzoate. Therefore, this demonstrates that the 4-bromophenyl triazole can be successfully used in conjunction with another type of chromophore for exciton-coupled CD analysis, with the added benefit of simplifying the corresponding conformational analysis.

\section{Conclusions}

A wide set of chiral mono- and di-1,4-disubstituted 1,2,3triazoles were synthesized by the 1,3-dipolar cycloaddition reaction between glycosyl azides and alkynes catalyzed by $\mathrm{Cu}+$ salts (CuAAC). The UV/CD spectroscopy study of these model compounds revealed that 4-substituted aryl triazoles give rise to large epsilon values and moderate 
exciton-coupled CD spectra, due to the rotamerism of the asymmetric aryl triazole chromophore.

Model compounds having the two chromophores in equatorial disposition exhibited their Cotton effects in agreement with the sign of the dihedral angle of the $\mathrm{C}-\mathrm{N}$ bonds. However, this was not the case for compounds with at least one chromophore in an axial disposition. They showed the opposite sign to that of the dihedral angle of their $\mathrm{C}-\mathrm{N}$ bonds. For these molecules, a conformational analysis is necessary to avoid erroneous determinations. Examination of the ${ }^{1} \mathrm{H}$ NMR chemical shifts is very useful, since the deshielding caused by the triazole ring reduces the number of conformations to be analyzed.

Among the 4-aryl triazoles, the 4-(4-bromo-phenyl)-1,2,3triazole in particular allows a red-shifted chromophore to be obtained via Suzuki reactions, which could be useful in some cases to avoid overlap with the substrate absorptions under study. Furthermore, the option of using a 4-aryl triazole chromophore together with another under a hetero exciton chirality coupling was also positively confirmed. In summary, 4-aryl 1,2,3-triazoles, especially 4-(4-bromophenyl)-1,2,3-triazole, could be used as chromophores for absolute stereochemical analysis of chiral molecules generated from click-chemistry azide-alkyne cycloaddition.

\section{Experimental}

4.1. General Information. ${ }^{1} \mathrm{H}$ NMR spectra were recorded at 500 and $600 \mathrm{MHz}$, and ${ }^{13} \mathrm{C} \mathrm{NMR}$ at 100,125 , and 150 $\mathrm{MHz}$, VTU $300.0{ }^{\circ} \mathrm{K}$. Chemical shifts are reported in parts per million. The residual solvent peak was used as an internal reference. HRMS were analyzed by TOF MS ES+. For analytical and preparative thin-layer chromatography, silica gel ready-foils and glass-backed plates $(1 \mathrm{~mm})$ were used, respectively, being developed with $254 \mathrm{~nm}$ UV light and/or spraying with $\mathrm{AcOH} / \mathrm{H}_{2} \mathrm{O} / \mathrm{H}_{2} \mathrm{SO}_{4}$ (80:16:4) and heating at $150{ }^{\circ} \mathrm{C}$. Column chromatography was performed using silica gel $(0.015-0.04 \mathrm{~mm})$ and $n$-hexane/EtOAc solvent systems. All reagents were obtained from commercial sources and used without further purification. Solvents were dried and distilled before use.

\subsection{Molecular mechanics and semi-empirical calculations. $^{23}$}

Initial structures were obtained from the PCModel program. A systematic search was performed around the $\mathrm{C}-\mathrm{N}$ bonds in steps of $30^{\circ}$, and selecting the MMX as the force field with a default dielectric constant of 1.5 Debye. The $g t$ orientation was taken into account for the hydroxymethyl group in the glucopyranoside di-triazoles. The generated structures were then optimized by semiempirical calculations using PM7, MOPAC2016.

\subsection{General Procedure for Glucopyranosyl Azides (Procedure A). ${ }^{11}$}

To a solution of the $O$-acetyl monosaccharide in dry $\mathrm{CH}_{2} \mathrm{Cl}_{2}$ (4 mL/mmol), TMS-N 3 (2.5 eq.) and $\mathrm{SnCl}_{4}(0.5$ eq.) were added under nitrogen. The reaction was stirred until the end (TLC). The mixture was then diluted with $\mathrm{CH}_{2} \mathrm{Cl}_{2}$, and an equal volume of saturated $\mathrm{NaHCO}_{3}$ solution was added and left for $30 \mathrm{~min}$. under stirring. Then, the mixture was extracted with $\mathrm{CH}_{2} \mathrm{Cl}_{2}$, dried over anhydrous $\mathrm{Na}_{2} \mathrm{SO}_{4}$, and evaporated in vacuum. The product was purified by flash column chromatography.

4.4. General Procedure for the CuAAC of 1,4Disubstituted 1,2,3-Triazoles (Procedure B). ${ }^{6}$

To a solution of the glucosylazide (1 equiv) in a $t$ $\mathrm{BuOH}-\mathrm{H}_{2} \mathrm{O} \quad 1: 1$ mixture $(2.8 \mathrm{~mL} / \mathrm{mmol})$, the alkyne $(1.1$ equiv), $1 \mathrm{M}$ aq $\mathrm{CuSO}_{4} \cdot 5 \mathrm{H}_{2} \mathrm{O}(0.01$ equiv), and $1 \mathrm{M}$ aq sodium ascorbate ( 0.1 equiv) were added. The reaction mixture was heated at $70{ }^{\circ} \mathrm{C}$ and reflux until TLC revealed no starting glucosylazide. The solvent was removed under reduced pressure, and the residue chromatographed on silica gel.

\subsection{General Procedure for the CuAAC of 1,4- Disubstituted 1,2,3-Triazoles (Procedure C). ${ }^{7}$}

To a solution of the glucosylazide ( 1 equiv) in $\mathrm{H}_{2} \mathrm{O}$ (5.6 $\mathrm{mL} / \mathrm{mmol}$ ), the alkyne (1.0 equiv), $1 \mathrm{M}$ aq $\mathrm{CuSO}_{4} \cdot 5 \mathrm{H}_{2} \mathrm{O}$ ( 0.015 equiv), and $1 \mathrm{M}$ aq sodium ascorbate ( 0.21 equiv) were added. The reaction mixture was heated at $70{ }^{\circ} \mathrm{C}$ with vigorous stirring until TLC revealed no starting glucosylazide. The solvent was removed under reduced pressure, and the residue chromatographed on silica gel.

\subsection{General Procedure for Deacetylation (Procedure D).}

To a solution of the acetylated compound in $\mathrm{CH}_{2} \mathrm{Cl}_{2}$ (5 $\mathrm{mL} / \mathrm{mmol}), \mathrm{MeOH}(10 \mathrm{~mL} / \mathrm{mmol})$ and sodium methoxide ( 2 equiv per acetyl group) were added. The mixture was stirred at room temperature until completion of the reaction (TLC), the solution was neutralized with Amberlite IR-120 Plus, solvent removed under reduced pressure, and the residue chromatographed in flash silica gel using $\mathrm{CH}_{2} \mathrm{Cl}_{2} / \mathrm{MeOH}$.

\subsection{2,3,4,6-Tetra- $O$-acetyl-1-azido-1-deoxy- $\beta$-D-gluco- pyranoside (1). ${ }^{27}$}

To a solution of 1,2,3,4,6-penta- $O$-acetyl $\alpha$-Dglucopyranose (405 mg, $1.04 \mathrm{mmol}$ ) in $4 \mathrm{~mL}$ of dry $\mathrm{CH}_{2} \mathrm{Cl}_{2}, \mathrm{TMS}-\mathrm{N}_{3}(360 \mu \mathrm{L}, 2.6 \mathrm{mmol})$ and $\mathrm{SnCl}_{4}(94 \mu \mathrm{L}$, $0.52 \mathrm{mmol})$ were added following Procedure A. The reaction product $(367.8 \mathrm{mg}$, 95\% yield) was used without purification. TLC $\mathrm{R}_{f}=0.43$ (n-hexane/EtOAc, 6:4); $[\alpha]_{\mathrm{D}}$ : -28.0 (c $\left.0.4, \mathrm{CHCl}_{3}\right)$; mp $124-125{ }^{\circ} \mathrm{C}$; IR $\left(\mathrm{cm}^{-1}\right) v_{\max } 2116$ $\left(\mathrm{N}_{3}\right), 1748(\mathrm{C}=\mathrm{O}), 1216$.

4.8. 2,3,4,6-Tetra- $O$-acetyl-1-(4-butyl-1H-1,2,3-triazol-1yl)-1-deoxy- $\beta$-D-glucopyranoside (2a).

Following procedure $\mathrm{B}$, to a solution of glucopyranosyl azide $1(300 \mathrm{mg}, 0.8 \mathrm{mmol})$ in $t-\mathrm{BuOH}-\mathrm{H}_{2} \mathrm{O}(1: 1,2.2 \mathrm{~mL})$, 
1-hexyne ( $0.88 \mathrm{mmol}, 104.2 \mu \mathrm{L}), 1 \mathrm{M}$ aq $\mathrm{CuSO}_{4} \cdot 5 \mathrm{H}_{2} \mathrm{O}$ $(0.08 \mathrm{mmol})$, and $1 \mathrm{M}$ aq sodium ascorbate $(0.8 \mathrm{mmol})$ were added. The residue was chromatographed on silica gel $n$ hexane/EtOAc (6:4) to give compound 2a (320.4 mg, 88\% yield). TLC $\mathrm{R}_{f}=0.23$ ( $n$-hexane/EtOAc, 6:4); mp $155^{\circ} \mathrm{C}$; $[\alpha]_{\mathrm{D}}$ : $-19.0\left(\mathrm{c} 2.1, \mathrm{CHCl}_{3}\right) ;{ }^{1} \mathrm{H} \mathrm{NMR}\left(500 \mathrm{MHz}, \mathrm{CDCl}_{3}\right) \delta$ $7.49(\mathrm{~s}, 1 \mathrm{H}), 5.84(\mathrm{~d}, J=9.0 \mathrm{~Hz}, \mathrm{H}-1), 5.43(\mathrm{dd}, J=9.5$ and $9.5 \mathrm{~Hz}, \mathrm{H}-2), 5.40(\mathrm{dd}, J=9.5$ and $9.5 \mathrm{~Hz}, \mathrm{H}-3), 5.22$ (dd, $J=9.3$ and $9.9 \mathrm{~Hz}, \mathrm{H}-4), 4.30(\mathrm{dd}, J=5.1$ and 12.6 $\mathrm{Hz}, \mathrm{H}-6$ ), 4.14 (dd, $J=2.1$ and $12.6 \mathrm{~Hz}, \mathrm{H}-6$ ) $), 3.98$ (ddd, $J=2.1,5.0$ and $10.1 \mathrm{~Hz}, \mathrm{H}-5), 2.71(\mathrm{dd}, J=7.4$ and 7.4 $\mathrm{Hz}, 2 \mathrm{H}), 2.07$ (s, 3H), $2.06(\mathrm{~s}, 3 \mathrm{H}), 2.02(\mathrm{~s}, 3 \mathrm{H}), 1.86$ (s, $3 \mathrm{H}), 1.65(\mathrm{~m}, 2 \mathrm{H}), 1.36(\mathrm{~m}, 2 \mathrm{H}), 0.93(\mathrm{dd}, J=7.4$ and 7.4 $\mathrm{Hz}, 3 \mathrm{H}) ;{ }^{13} \mathrm{C}$ NMR $\left(125 \mathrm{MHz}, \mathrm{CDCl}_{3}\right) \delta 170.4(\mathrm{~s}), 169.8$ (s), $169.3(\mathrm{~s}), 169.0(\mathrm{~s}), 118.7$ (d), 149.8 (s), 85.7 (d, C-1), 75.1 (d, C-5), 72.8 (d, C-3), $70.2(\mathrm{~d}, \mathrm{C}-2), 67.8$ (d, C-4), $61.6(\mathrm{t}, \mathrm{C}-6), 31.2(\mathrm{t}), 25.3(\mathrm{t}), 22.1(\mathrm{t}), 20.6(\mathrm{q}), 20.5(\mathrm{q})$, 20.4 (q), 20.1 (q), 13.7 (q); HRMS (ESI) calcd. for $\mathrm{C}_{20} \mathrm{H}_{29} \mathrm{~N}_{3} \mathrm{O}_{9} \mathrm{Na} \quad[\mathrm{M}+\mathrm{Na}]+:$ 478.1807, found: 478.1807; Anal. calcd. for $\mathrm{C}_{20} \mathrm{H}_{29} \mathrm{~N}_{3} \mathrm{O}_{9}: \mathrm{C}, 52.74 ; \mathrm{H}, 6.42 ; \mathrm{N}, 9.23$, found $\mathrm{C}, 52.56 ; \mathrm{H}, 6.41 ; \mathrm{N}, 9.18 ; \mathrm{UV}\left(\mathrm{CH}_{3} \mathrm{CN}\right) \lambda_{\max }(\varepsilon)$ : $220 \mathrm{~nm}$ (3940); $\mathrm{CD}\left(\mathrm{CH}_{3} \mathrm{CN}\right) \lambda_{\text {ext }}(\Delta \varepsilon): 220(-1.1), 295 \mathrm{~nm}$ $(+0.2)$.

\subsection{2,3,4,6-Tetra- $O$-acetyl-1-deoxy-1-(4-methoxy- carbonyl-1H-1,2,3-triazol-1-yl)- $\beta$-D-glucopyranoside $(2 b){ }^{6}$}

Prepared from glucopyranosyl azide 1 (368 mg (0.97 mmol) and methyl propiolate $(89.7 \mathrm{mg}, 1.07 \mathrm{mmol})$ following Procedure B. The product was chromatographed on flash silica gel using $n$-hexane/EtOAc (8:2) $(190.7 \mathrm{mg}$, $43 \%$ yield). TLC R $\mathrm{R}_{f}=0.11$ (n-hexane/EtOAc, 6:4); mp 205$207{ }^{\circ} \mathrm{C} ;[\alpha]_{\mathrm{D}}:-28.0\left(\mathrm{c} 2.1, \mathrm{CHCl}_{3}\right) ; \mathrm{UV}\left(\mathrm{CH}_{3} \mathrm{CN}\right) \lambda_{\max }(\varepsilon)$ : $211 \mathrm{~nm}(11700) ; \mathrm{CD}\left(\mathrm{CH}_{3} \mathrm{CN}\right) \lambda_{\mathrm{ext}}(\Delta \varepsilon): 219(-3.4), 286$ $\mathrm{nm}(+0.7)$.

\subsection{2,3,4,6-Tetra- $O$-acetyl-1-deoxy-1-(4-hydroxy- methyl-1H-1,2,3-triazol-1-yl)- $\beta$-D-glucopyranoside (2c). ${ }^{6,7}$}

Prepared from glucopyranosyl azide 1 (63.3 mg, 0.17 mmol) and propargylic alcohol (43 $\mu \mathrm{L}, 0.7 \mathrm{mmol}$ ) following Procedure B. The product was chromatographed on flash silica gel using $n$-hexane/EtOAc $(6: 4)(52.5 \mathrm{mg}$, $72 \%$ yield). TLC $\mathrm{R}_{f}=0.22$ ( $n$-hexane/EtOAc, 2:8); mp $148-150{ }^{\circ} \mathrm{C} ;[\alpha]_{\mathrm{D}}:-6.0\left(\mathrm{c}=1.0, \mathrm{CHCl}_{3}\right) ; \mathrm{UV}\left(\mathrm{CH}_{3} \mathrm{CN}\right)$ $\lambda_{\max }(\varepsilon): 218 \mathrm{~nm}(3900) ; \mathrm{CD}\left(\mathrm{CH}_{3} \mathrm{CN}\right) \lambda_{\text {ext }}(\Delta \varepsilon): 220 \mathrm{~nm}$ $(-1.3)$.

4.11. 2,3,4,6-Tetra- $O$-acetyl-1-deoxy-1-(4-phenyl-1H1,2,3-triazol-1-yl)- $\beta$-D-glucopyranoside (2d). ${ }^{6,7}$

Glucopyranosyl azide 1 (100 $\mathrm{mg}, 0.27 \mathrm{mmol})$ and phenylacetylene $(30.3 \mu \mathrm{L}, 0.27 \mathrm{mmol})$ were allowed to react following Procedure $\mathrm{C}$. The product was chromatographed on flash silica gel using $n$-hexane/EtOAc (7:3) $\quad(74.4 \mathrm{mg}, 58 \%$ yield $)$ TLC $\mathrm{R}_{f}=0.28 \quad(n-$ hexane/EtOAc, 5:5); mp 213-215 ${ }^{\circ} \mathrm{C}$; $[\alpha]_{\mathrm{D}}$ : -49.0 (c 2.1,
$\left.\mathrm{CHCl}_{3}\right) ; \mathrm{UV}\left(\mathrm{CH}_{3} \mathrm{CN}\right) \lambda_{\max }(\varepsilon): 243 \mathrm{~nm}$ (15000); $\mathrm{CD}$ $\left(\mathrm{CH}_{3} \mathrm{CN}\right) \lambda_{\text {ext }}(\Delta \varepsilon): 231(-3.4), 220 \mathrm{~nm}(-3.3)$.

4.12. 2,3,4,6-Tetra- $O$-acetyl-1-deoxy-1-(4-p-methylphenyl-1H-1,2,3-triazol-1-yl)- $\beta$-D-glucopyranoside (2e). ${ }^{28}$

Prepared from azide $\mathbf{1}(104 \mathrm{mg}, 0.28 \mathrm{mmol})$ and 4-ethynyl toluene $(36.5 \mu \mathrm{L})$ following Procedure $\mathrm{C}$. The product was chromatographed on flash silica gel using $n$-hexane/EtOAc (7:3) $\quad(61.6 \mathrm{mg}, \quad 45 \%$ yield $)$. TLC $\mathrm{R}_{f}=0.48 \quad(n-$ hexane/EtOAc, 5:5); mp 230-231 ${ }^{\circ} \mathrm{C}$; $[\alpha]_{\mathrm{D}}$ : -48.0 (c 1.8, $\left.\mathrm{CHCl}_{3}\right) ;{ }^{1} \mathrm{H}$ NMR $\left(500 \mathrm{MHz}, \mathrm{CDCl}_{3}\right) \delta 7.94(\mathrm{~s}, 1 \mathrm{H}), 7.72$ $(\mathrm{d}, J=8.1 \mathrm{~Hz}, 2 \mathrm{H}), 7.24(\mathrm{~d}, J=8.0 \mathrm{~Hz}, 2 \mathrm{H}), 5.92(\mathrm{~d}, J=$ $9.4 \mathrm{~Hz}, \mathrm{H}-1), 5.52(\mathrm{dd}, J=9.5$ and $9.5 \mathrm{~Hz}, \mathrm{H}-2), 5.44(\mathrm{dd}$, $J=9.4$ and $9.5 \mathrm{~Hz}, \mathrm{H}-3), 5.27(\mathrm{dd}, J=9.9$ and $9.6 \mathrm{~Hz}$, $\mathrm{H}-4), 4.33(\mathrm{dd}, J=5.1$ and $12.7 \mathrm{~Hz}, \mathrm{H}-6), 4.16(\mathrm{dd}, J=2.0$ and $\left.12.6 \mathrm{~Hz}, \mathrm{H}-6^{\prime}\right) 4.03$ (ddd, $J=2.0,5.1$ and $10.1 \mathrm{~Hz}$, $\mathrm{H}-5), 2.38$ (s, 3H), 2.09 (s, 3H), 2.08 (s, 3H), 2.04 (s, 3H), $1.88(\mathrm{~s}, 3 \mathrm{H}) .{ }^{13} \mathrm{C}$ NMR $\left(125 \mathrm{MHz}, \mathrm{CDCl}_{3}\right) \delta 170.5$ (s), $169.9(\mathrm{~s}), 169.3(\mathrm{~s}), 168.9(\mathrm{~s}), 148.6(\mathrm{~s}), 138.4(\mathrm{~s}), 129.5(\mathrm{~d}$, 2C), 127.1 (s), 125.8 (d, 2C), 117.4 (d), 85.8 (d, C-1), 75.1 (d, C-5), 72.8 (d, C-3), 70.2 (d, C-2), 67.8 (d, C-4), 61.6 (t, C-6), 21.3 (q), 20.6 (q), 20.5 (q), 20.5 (q), 20.1 (q); HRMS (ESI) calcd. for $\mathrm{C}_{23} \mathrm{H}_{27} \mathrm{~N}_{3} \mathrm{O}_{9} \mathrm{Na}$ [M+Na] $]^{+}$: 512.1645, found: 512.1646; $\mathrm{UV}\left(\mathrm{CH}_{3} \mathrm{CN}\right) \lambda_{\max }(\varepsilon): 248 \mathrm{~nm}(18800)$; $\mathrm{CD}\left(\mathrm{CH}_{3} \mathrm{CN}\right) \lambda_{\text {ext }}(\Delta \varepsilon): 244(-3.8), 295 \mathrm{~nm}(+0.8)$.

4.13. 2,3,4,6-Tetra- $O$-acetyl-1-[4-(4-bromophenyl)-1H1,2,3-triazol-1-yl]-1-deoxy- $\beta$-D-glucopyranoside (2f).

Prepared from azide 1 (350 mg, $0.94 \mathrm{mmol})$ and 1-bromo4-ethynyl benzene $(170.3 \mathrm{mg}, 0.94 \mathrm{mmol})$ following Procedure $\mathrm{C}$. The product was chromatographed on flash silica gel using $n$-hexane/EtOAc (7:3) $(337.9 \mathrm{mg}, 65 \%$ yield). TLC $\mathrm{R}_{f}=0.36$ ( $n$-hexane/EtOAc, 5:5); mp 261-262 ${ }^{\circ} \mathrm{C} ;[\alpha]_{\mathrm{D}}:-54.0$ (c 1.9, $\mathrm{CHCl}_{3}$ ); ${ }^{1} \mathrm{H}$ NMR $(500 \mathrm{MHz}$, $\left.\mathrm{CDCl}_{3}\right) \delta 8.00(\mathrm{~s}, 1 \mathrm{H}), 7.71(\mathrm{~d}, J=8.5 \mathrm{~Hz}, 2 \mathrm{H}), 7.56(\mathrm{~d}, J=$ $8.5 \mathrm{~Hz}, 2 \mathrm{H}), 5.92(\mathrm{~d}, J=9.2 \mathrm{~Hz}, \mathrm{H}-1), 5.50(\mathrm{dd}, J=9.5$ and $9.3 \mathrm{~Hz}, \mathrm{H}-2), 5.44(\mathrm{dd}, J=9.2$ and $9.5 \mathrm{~Hz}, \mathrm{H}-3), 5.26$ (dd, $J=9.3$ and $10.0 \mathrm{~Hz}, \mathrm{H}-4), 4.33$ (dd, $J=5.1$ and 12.7 $\mathrm{Hz}, \mathrm{H}-6$ ), 4.16 (dd, $J=2.1$ and $12.7 \mathrm{~Hz}, \mathrm{H}-6$ ), 4.03 (ddd, $J=2.1,5.1$ and $10.2 \mathrm{~Hz}, \mathrm{H}-5), 2.09(\mathrm{~s}, 3 \mathrm{H}), 2.08(\mathrm{~s}, 3 \mathrm{H})$, $2.04(\mathrm{~s}, 3 \mathrm{H}), 1.89(\mathrm{~s}, 3 \mathrm{H}) ;{ }^{13} \mathrm{C}$ NMR $\left(125 \mathrm{MHz}, \mathrm{CDCl}_{3}\right) \delta$ $170.4(\mathrm{~s}), 169.9(\mathrm{~s}), 169.3(\mathrm{~s}), 169.0(\mathrm{~s}), 147.4(\mathrm{~s}), 132.0(\mathrm{~d}$, 2C), 128.9 (s), 127.4 (d, 2C), 122.5 (s), 117.8 (d), 85.9 (d, C-1), 75.3 (d, C-5), 72.7 (d, C-3), 70.2 (d, C-2), 67.7 (d, C-4), 61.6 (t, C-6), 20.7 (q), 20.5 (q), 20.5 (q), 20.2 (q); HRMS (ESI) calcd. for $\mathrm{C}_{22} \mathrm{H}_{24} \mathrm{BrN}_{3} \mathrm{O}_{9} \mathrm{Na}\left[\mathrm{M}+\mathrm{Na}\left({ }^{79} \mathrm{Br}\right)\right]^{+}$: 576.0644, found: 576.0647 ; calcd. for $\mathrm{C}_{22} \mathrm{H}_{24} \mathrm{BrN}_{3} \mathrm{O} 9 \mathrm{Na}$ $\left[\mathrm{M}+\mathrm{Na}\left({ }^{81} \mathrm{Br}\right)\right]^{+}:$578.0634, found: 578.0624 . Anal. calcd. for $\mathrm{C}_{22} \mathrm{H}_{24} \mathrm{BrN}_{3} \mathrm{O}_{9}$ : $\mathrm{C}, 47.67 ; \mathrm{H}, 4.37 ; \mathrm{N}, 7.59$, found $\mathrm{C}$, 47.47; H, 4.39; N, 7.63; UV $\left(\mathrm{CH}_{3} \mathrm{CN}\right) \lambda_{\max }(\varepsilon): 254 \mathrm{~nm}$ (25500); $\mathrm{CD}\left(\mathrm{CH}_{3} \mathrm{CN}\right) \lambda_{\text {ext }}(\Delta \varepsilon): 247$ (-4.3), $290 \mathrm{~nm}(+0.6)$.

4.14. 2,3,4,6-Tetra- $O$-acetyl-1-deoxy-1-[4-(6-methoxy-2naphthyl)-1H-1,2,3-triazol-1-yl]- $\beta$-D-glucopyranoside $(2 \mathrm{~g}){ }^{29}$ 
Prepared from azide 1 (209 mg, 0.56mmol) and 2-ethynyl6-methoxynaphthalene $(102.5 \mathrm{mg}, 0.56 \mathrm{mmol})$ following Procedure C. The product was chromatographed on flash silica gel using $n$-hexane/EtOAc (5:5) (289.1 mg, 93\% yield). TLC $\mathrm{R}_{f}=0.32$ ( $n$-hexane/EtOAc, 5:5); mp 252-253 ${ }^{\circ} \mathrm{C} ;[\alpha]_{\mathrm{D}}$ : -85.0 (c 2.3, $\mathrm{CHCl}_{3}$ ); HRMS (ESI) calcd. for $\mathrm{C}_{27} \mathrm{H}_{29} \mathrm{~N}_{3} \mathrm{O}_{10} \mathrm{Na} \quad[\mathrm{M}+\mathrm{Na}]^{+}$: 578.1751, found: 578.1755 . Anal. calcd. for $\mathrm{C}_{27} \mathrm{H}_{29} \mathrm{~N}_{3} \mathrm{O}_{10}$ : C, 58.37; $\mathrm{H}, 5.26 ; \mathrm{N}, 7.56$, found $\mathrm{C}, 58.33 ; \mathrm{H}, 5.43 ; \mathrm{N}, 7.23 ; \mathrm{UV}\left(\mathrm{CH}_{3} \mathrm{CN}\right) \lambda_{\max }(\varepsilon)$ : 245 (49400), 255 sh (46700), 288 (14000), 298 (13300), $344 \mathrm{~nm}$ (1000); $\mathrm{CD}\left(\mathrm{CH}_{3} \mathrm{CN}\right) \lambda_{\text {ext }}(\Delta \varepsilon): 245(-6.4), 295 \mathrm{~nm}$ $(+0.6)$.

\subsection{5. $2,3,4,6$-Tetra- $O$-acetyl-1-azido-1-deoxy- $\alpha$-D-gluco- pyranoside (3). ${ }^{13}$}

To a solution of $\beta$-D-glucose pentaacetate $(500 \mathrm{mg}, 1.28$ $\mathrm{mmol}$ ) in $2.6 \mathrm{~mL}$ of dry $\mathrm{CH}_{2} \mathrm{Cl}_{2}$ under nitrogen, $\mathrm{PCl}_{5}$ (293.6 $\mathrm{mg}, 1.41 \mathrm{mmol})$ and $\mathrm{BF}_{3} \cdot \mathrm{OEt}_{2}(2.6 \mu \mathrm{l}, 2 \mu \mathrm{l} / \mathrm{mmol})$ were added at room temperature, and the reaction stirred until completion (TLC). Then, it was diluted with $\mathrm{CH}_{2} \mathrm{Cl}_{2}$ and extracted with first a saturated $\mathrm{NaHCO}_{3}$ solution and then with water. The organic layer was dried over $\mathrm{Na}_{2} \mathrm{SO}_{4}$, and evaporated in vacuum. To the product $(468.6 \mathrm{mg}, 1.28$ $\mathrm{mmol})$ in dry THF $(12.8 \mathrm{~mL}, 10 \mathrm{~mL} / \mathrm{mmol})$ under nitrogen, $\mathrm{TMSN}_{3}(0.25 \mathrm{~mL}, 1.8 \mathrm{mmol})$ and $1 \mathrm{M}$ TBAF in THF(1.8 $\mathrm{mL}, 1.4 \mathrm{~mL} / \mathrm{mmol}$ ) were added. The mixture was stirred at $65{ }^{\circ} \mathrm{C}$ until completion of the reaction (TLC) and the solvent removed under reduced pressure. The anomeric residue $(\alpha: \beta$ 1:0.25) was chromatographed on flash silica gel using $n$-hexane/EtOAc (7:3) to give compound 3 (178.9 $\mathrm{mg}, 31 \%$ overall yield). Spectroscopic data are consistent with those reported in ref. 13.

\subsection{2,3,4,6-Tetra- $O$-acetyl-1-(4-butyl-1H-1,2,3-triazol- 1-yl)-1-deoxy- $\alpha$-D-glucopyranoside (4a).}

Prepared from glucopyranosyl azide $3(54.8 \mathrm{mg}, 0.15$ mmol) and 1-hexyne $(20.9 \mu \mathrm{L}, 0.18$ mmoles $)$ following Procedure C. The product was chromatographed on flash silica gel using $n$-hexane/EtOAc (7:3) $(63.5 \mathrm{mg}, 93 \%$ yield). TLC $\mathrm{R}_{f}=0.23$ ( $n$-hexane/EtOAc, 6:4); mp 110-112 ${ }^{\circ} \mathrm{C} ;[\alpha]_{\mathrm{D}}:+105.8\left(\mathrm{c} 0.1, \mathrm{CHCl}_{3}\right) ;{ }^{1} \mathrm{H}$ NMR $(600 \mathrm{MHz}$, $\left.\mathrm{CDCl}_{3}\right) \delta 7.33(\mathrm{~s}, 1 \mathrm{H}) 6.28(\mathrm{~d}, J=6.1 \mathrm{~Hz}, \mathrm{H}-1), 6.24(\mathrm{dd}, J$ $=9.3$ and $10.0 \mathrm{~Hz}, \mathrm{H}-3), 5.25(\mathrm{dd}, J=6.1$ and $10.1 \mathrm{~Hz}$, $\mathrm{H}-2), 5.21$ (dd, $J=9.3$ and $10.3 \mathrm{~Hz}, \mathrm{H}-4$ ) , 4.32 (m, H-5), $4.21(\mathrm{dd}, J=3.8$ and $12.7 \mathrm{~Hz}, \mathrm{H}-6), 3.98(\mathrm{dd}, J=1.9$ and $12.6 \mathrm{~Hz}, \mathrm{H}-6$ '), 2.71 (dd, $J=7.6$ and $7.7 \mathrm{~Hz}, 2 \mathrm{H}), 2.03$ (s, $3 \mathrm{H}), 2.01(\mathrm{~s}, 3 \mathrm{H}), 1.99$ (s, 3H), 1.83 (s, 3H), 1.63 (m, 2H), $1.34(\mathrm{~m}, 2 \mathrm{H}), 0.90(\mathrm{dd}, J=7.3$ and $7.4 \mathrm{~Hz}, 3 \mathrm{H}) ;{ }^{13} \mathrm{C} \mathrm{NMR}$ $\left(150 \mathrm{MHz}, \mathrm{CDCl}_{3}\right) \delta 170.4(\mathrm{~s}), 170.2$ (s), 169.7 (s), 169.5 (s), 147.9 (s), 122.8 (d), 80.9 (d, C-1), 70.8 (d, C-5), 70.4 (d, C-3), 69.8 (d, C-2), 67.9 (d, C-4), 61.1 (t, C-6), 31.1 $(\mathrm{t}), 24.9(\mathrm{t}), 22.1(\mathrm{t}), 20.6(\mathrm{q}), 20.6(\mathrm{q}), 20.5(\mathrm{q}), 20.2(\mathrm{q})$, 13.7 (q); MS (EI) m/z (rel. intensity) 331 ([ $\mathrm{M}^{+}-$aglicone], 9), 169 (100), 109 (85). Anal. calcd. for $\mathrm{C}_{20} \mathrm{H}_{29} \mathrm{~N}_{3} \mathrm{O}_{9}$ : C, 52.74; H, 6.42; N, 9.23, found C, 52.68; H, 6.58; N, 9.39; $\mathrm{UV}\left(\mathrm{CH}_{3} \mathrm{CN}\right) \lambda_{\max }(\varepsilon): 221 \mathrm{~nm}(3940) ; \mathrm{CD}\left(\mathrm{CH}_{3} \mathrm{CN}\right) \lambda_{\text {ext }}$ $(\Delta \varepsilon)$ : br $217(-0.5), 290 \mathrm{~nm}(+0.1)$.
4.17. 2,3,4,6-Tetra-O-acetyl-1-[4-(4-bromophenyl)-1H1,2,3-triazol-1-yl]-1-deoxy- $\alpha$-D-glucopyranoside (4f).

Prepared from glucopyranosyl azide $3(51.7 \mathrm{mg}, 0.14$ $\mathrm{mmol}$ ) and 1-bromo-4-ethynyl benzene (30.4 mg, 0.17 mmol) following Procedure $\mathrm{C}$. The product was chromatographed on flash silica gel using $n$-hexane/EtOAc (6:7) $\quad(57.3 \mathrm{mg}, \quad 74 \%$ yield $)$. TLC $\mathrm{R}_{f}=0.36 \quad(n-$ hexane/EtOAc, 5:5); mp 224-226 ${ }^{\circ} \mathrm{C} ;[\alpha]_{\mathrm{D}}:+114.7$ (c 0.1 , $\left.\mathrm{CHCl}_{3}\right) ;{ }^{1} \mathrm{H} \mathrm{NMR}\left(600 \mathrm{MHz}, \mathrm{CDCl}_{3}\right) \delta 7.88(\mathrm{~s}, 1 \mathrm{H}), 7.72$ $(\mathrm{d}, J=8.5 \mathrm{~Hz}, 2 \mathrm{H}), 7.56(\mathrm{~d}, J=8.5 \mathrm{~Hz}, 2 \mathrm{H}), 6.41(\mathrm{~d}, J=$ $6.1 \mathrm{~Hz}, \mathrm{H}-1), 6.32(\mathrm{dd}, J=9.7$ and $9.7 \mathrm{~Hz}, \mathrm{H}-3), 5.32$ (dd, $J=6.0$ and $10.0 \mathrm{~Hz}, \mathrm{H}-2), 5.26(\mathrm{dd}, J=9.63$ and $10.0 \mathrm{~Hz}$, $\mathrm{H}-4), 4.34$ (m, H-5), 4.24 (dd, $J=3.9$ and $12.8 \mathrm{~Hz}, \mathrm{H}-6)$, $4.01(\mathrm{dd}, J=2.1$ and $12.7 \mathrm{~Hz}, \mathrm{H}-6$ '), 2.05 (s, 3H), 2.04 (s, $3 \mathrm{H}), 2.03(\mathrm{~s}, 3 \mathrm{H}), 1.86(\mathrm{~s}, 3 \mathrm{H}) ;{ }^{13} \mathrm{C} \mathrm{NMR}(150 \mathrm{MHz}$, $\left.\mathrm{CDCl}_{3}\right) \delta 170.4(\mathrm{~s}), 170.2(\mathrm{~s}), 169.7$ (s), $169.6(\mathrm{~s}), 146.2$ (s), 132.1 (d, 2C), 128.6 (s), 127.2 (d, 2C), 122.5 (s), 121.8 (d), 81.4 (d, C-1), 71.1 (d, C-5), 70.3 (d, C-3), 69.8 (d, C-2), 67.9 (d, C-4), 61.1 (t, C-6), 20.6 (q), 20.6 (q), 20.5 (q), 20.3 (q); MS (EI) m/z (rel. intensity) $556\left(\left[\mathrm{M}\left({ }^{81} \mathrm{Br}\right)\right]^{+}, 1\right)$; 554 ([M ( $\left.\left.\left.{ }^{79} \mathrm{Br}\right)\right]^{+}, 1\right), 331$ (17), 224 (5), 169 (100), 109 (68); HRMS (EI) calcd. for $\mathrm{C}_{22} \mathrm{H}_{24} \mathrm{BrN}_{3} \mathrm{O}_{9} \quad\left[\mathrm{M} \quad\left({ }^{79} \mathrm{Br}\right)\right]^{+}$: 553.0696, found: 553.0701; calcd. for $\mathrm{C}_{22} \mathrm{H}_{24} \mathrm{BrN}_{3} \mathrm{O}_{9}[\mathrm{M}$ $\left.\left({ }^{81} \mathrm{Br}\right)\right]^{+}$: 555.0675, found: 555.0662. Anal. calcd. for $\mathrm{C}_{22} \mathrm{H}_{24} \mathrm{BrN}_{3} \mathrm{O}_{9}: \mathrm{C}, 47.67 ; \mathrm{H}, 4.37 \mathrm{~N}, 7.59$, found $\mathrm{C}, 47.79$; $\mathrm{H}, 4.60 ; \mathrm{N}, 7.86$; UV $\left(\mathrm{CH}_{3} \mathrm{CN}\right) \lambda_{\max }(\varepsilon): 254 \mathrm{~nm}(25500)$; $\mathrm{CD}\left(\mathrm{CH}_{3} \mathrm{CN}\right) \lambda_{\text {ext }}(\Delta \varepsilon): 252$ (+2.9), $286 \mathrm{~nm}(+0.9)$.

\subsection{2,3,4,6-Tetra- $O$-acetyl-1-deoxy-1-[4-(6-methoxy-2- naphthyl)-1H-1,2,3-triazol-1-yl]- $\alpha$-D-glucopyranoside (4g).}

Glucopyranosyl azide 3 (52.7 $\mathrm{mg}, 0.14 \mathrm{mmol}$ ) and 2ethynyl-6-methoxynaphthalene $(30.6 \mathrm{mg}, 0.17 \mathrm{mmol})$ were allowed to react following Procedure $\mathrm{C}$, and the product was chromatographed on flash silica gel using $n$ hexane/EtOAc (5:5) (90.6 mg, 96\% yield).TLC $\mathrm{R}_{f}=0.32$ (n-hexane/EtOAc, 5:5); mp 204-206 ${ }^{\circ} \mathrm{C} ;[\alpha]_{\mathrm{D}}:+121.6$ (c $\left.0.1, \mathrm{CHCl}_{3}\right) ;{ }^{1} \mathrm{H}$ NMR $\left(600 \mathrm{MHz}, \mathrm{CDCl}_{3}\right) \delta 8.26(\mathrm{~s}, 1 \mathrm{H})$, $7.94(\mathrm{~s}, 1 \mathrm{H}), 7.90(\mathrm{dd}, J=1.4$ and $8.5 \mathrm{~Hz}, 1 \mathrm{H}), 7.78(\mathrm{dd}, J$ $=9.3$ and $10.3 \mathrm{~Hz}, 2 \mathrm{H}), 7.16(\mathrm{dd}, J=2.5$ and $8.8 \mathrm{~Hz}, 1 \mathrm{H})$, $7.13(\mathrm{~d}, J=2.1 \mathrm{~Hz}, 1 \mathrm{H}), 6.44(\mathrm{~d}, J=6.1 \mathrm{~Hz}, \mathrm{H}-1), 6.37$ $(\mathrm{dd}, J=9.5$ and $9.7 \mathrm{~Hz}, \mathrm{H}-3), 5.35(\mathrm{dd}, J=6.1$ and 10.0 $\mathrm{Hz}, \mathrm{H}-2), 5.29$ (dd, $J=9.4$ and $10.1 \mathrm{~Hz}, \mathrm{H}-4), 4.40(\mathrm{~m}$, $\mathrm{H}-5), 4.27$ (dd, $J=3.9$ and $12.7 \mathrm{~Hz}, \mathrm{H}-6), 4.03$ (dd, $J=2.0$ and $12.7 \mathrm{~Hz}, \mathrm{H}-6$ '), $3.92(\mathrm{~s}, 3 \mathrm{H}), 2.06$ (s, 3H), 2.06 (s, 3H), $2.04(\mathrm{~s}, 3 \mathrm{H}), 1.88$ (s, 3H); $\left.{ }^{13} \mathrm{C} \mathrm{NMR} \mathrm{(150} \mathrm{MHz,} \mathrm{CDCl}_{3}\right)$ $\delta 170.4$ (s), 170.3 (s), 169.7 (s), 169.6 (s), 158.0 (s), 147.4 (s), $134.5(\mathrm{~s}), 129.7(\mathrm{~d}), 128.8(\mathrm{~s}), 127.5(\mathrm{~d}), 124.8(\mathrm{~s})$, 124.5 (d), 124.1 (d), 121.5 (d), 119.4 (d), 105.7 (d), 81.4 (d, C-1), 71.0 (d, C-5), 70.4 (d, C-3), 69.8 (d, C-2), 67.9 (d, C-4), 61.2 (t, C-6), 55.2 (q), 20.6 (q), 20.6 (q), 20.6 (q), 20.3 (q); MS (EI) m/z (rel. intensity) $556\left([\mathrm{M}+1]^{+}, 2\right) ; 555$ ([M] $\left.]^{+}, 7\right) ; 365$ (27), 225 (35), 196 (100), 109 (55); HRMS (EI) calcd. for $\mathrm{C}_{27} \mathrm{H}_{29} \mathrm{~N}_{3} \mathrm{O}_{10}\left[\mathrm{M}^{+}\right]$: 555.1853, found: 555.1866; Anal. calcd. for $\mathrm{C}_{27} \mathrm{H}_{29} \mathrm{~N}_{3} \mathrm{O}_{10}$ : C, 58.37; $\mathrm{H}, 5.26$; $\mathrm{N}, 7.56$, found $\mathrm{C}, 58.05 ; \mathrm{H}, 5.14 ; \mathrm{N}, 7.85 ; \mathrm{UV}\left(\mathrm{CH}_{3} \mathrm{CN}\right)$ 
$\lambda_{\max }(\varepsilon): 245$ (49400), 254 sh (46700), 288 (14000), 298 (13300), $344 \mathrm{~nm}(1000) ; \mathrm{CD}\left(\mathrm{CH}_{3} \mathrm{CN}\right) \lambda_{\text {ext }}(\Delta \varepsilon): 245$ (+3.3), $253(+4.1), 290 \mathrm{~nm}(+2.7)$.

\subsection{1-(4-Butyl-1H-1,2,3-triazol-1-yl)-1-deoxy- $\beta$-gluco- pyranoside (5a).}

Triazole 2a (150 mg, $0.33 \mathrm{mmol})$ was deacetylated following Procedure D and the product chromatographed on flash silica gel using $\mathrm{CH}_{2} \mathrm{Cl}_{2} / \mathrm{MeOH}(9: 1)(81.4 \mathrm{mg}$, $86 \%$ yield). TLC $\mathrm{R}_{f}=0.47\left(\mathrm{CH}_{2} \mathrm{Cl}_{2} / \mathrm{MeOH} 85: 15\right) ;[\alpha]_{\mathrm{D}}$ -9.0 (c 3.0, MeOH); ${ }^{1} \mathrm{H}$ NMR $\left(500 \mathrm{MHz}, \mathrm{CD}_{3} \mathrm{OD}\right) \delta 7.96$ $(\mathrm{s}, 1 \mathrm{H}), 5.59(\mathrm{~d}, J=9.2 \mathrm{~Hz}, \mathrm{H}-1), 3.92(\mathrm{dd}, J=9.0$ and 9.0 $\mathrm{Hz}, \mathrm{H}-2), 3.91$ (dd, $J=2.2$ and $11.8 \mathrm{~Hz}, \mathrm{H}-6), 3.74$ (dd, $J$ $=5.4$ and $12.2 \mathrm{~Hz}, \mathrm{H}-6$ ), $3.54(\mathrm{~m}, \mathrm{H}-3$ and $\mathrm{H}-5,3.52$ (dd, $J=9.2$ and $9.2 \mathrm{~Hz}, \mathrm{H}-4), 2.75(\mathrm{dd}, J=7.6$ and $7.6 \mathrm{~Hz}, 2 \mathrm{H})$, $1.69(\mathrm{~m}, 2 \mathrm{H}), 1.43(\mathrm{~m}, 2 \mathrm{H}), 0.98(\mathrm{dd}, J=7.4$ and $7.4 \mathrm{~Hz}$, $3 \mathrm{H}) ;{ }^{13} \mathrm{C}$ NMR (100 MHz, CD $\left.3 \mathrm{OD}\right) \delta 150.0$ (s), 123.2 (d), 90.3 (d, C-1), 81.9 (d, C-3*), 79.4 (d, C-5*), 74.8 (d, C-2), $71.7(\mathrm{~d}, \mathrm{C}-4), 63.2(\mathrm{t}, \mathrm{C}-6), 33.5(\mathrm{t}), 26.8(\mathrm{t}), 24.0$ (t), 14.9 (q); HRMS (ESI) calcd. for $\mathrm{C}_{12} \mathrm{H}_{21} \mathrm{~N}_{3} \mathrm{O}_{5} \mathrm{Na}$ $[\mathrm{M}+\mathrm{Na}]^{+}$: 310.1379 , found: 310.1379; Anal. calcd. for $\mathrm{C}_{12} \mathrm{H}_{21} \mathrm{~N}_{3} \mathrm{O}_{5}$ : C, 50.16; $\mathrm{H}, 7.37 ; \mathrm{N}, 14.63$, found $\mathrm{C}, 50.01$; $\mathrm{H}, 7.48 ; \mathrm{N}, 14.74$; UV $\left(\mathrm{CH}_{3} \mathrm{OH}\right) \lambda_{\max }(\varepsilon): 221 \mathrm{~nm}(1900)$; $\mathrm{CD}\left(\mathrm{CH}_{3} \mathrm{OH}\right) \lambda_{\text {ext }}(\Delta \varepsilon): 213 \mathrm{~nm}(-1.2)$.

\subsection{0. $2,3,4,6$-Tetra- $O$-acetyl- $\alpha$-D-mannopyranosyl azide (6)..$^{30}$}

To a solution of $(500 \mathrm{mg}, 1.28 \mathrm{mmol})$ in $5 \mathrm{~mL}$ of dry $\mathrm{CH}_{2} \mathrm{Cl}_{2}, \mathrm{TMS}^{-\mathrm{N}_{3}}(440 \mu \mathrm{L}, 3.2 \mathrm{mmol})$ and $\mathrm{SnCl}_{4}(115 \mu \mathrm{L}$, $0.64 \mathrm{mmol}$ ) were added following Procedure A. The reaction product (480 $\mathrm{mg}$, quant.) was used without purification. TLC $\mathrm{R}_{f}=0.77$ (n-hexane/EtOAc, 7:3); NMR data of this compound are consistent with those reported in ref. 30 .

4.21. 2,3,4,6-Tetra- $O$-acetyl-1-[4-(4-bromophenyl)-1H1,2,3-triazol-1-yl]-1-deoxy- $\beta$-D-mannopyranoside (7f).

Prepared from azide 1 (110 mg, $0.3 \mathrm{mmol}$ ) and 1-bromo-4ethynyl benzene $(54.3 \mathrm{mg}, 0.3 \mathrm{mmol})$ following Procedure C. The product was chromatographed on flash silica gel using $n$-hexane/EtOAc (6:4) $(151 \mathrm{mg}, 97 \%$ yield). TLC R $=0.25(n$-hexane/EtOAc, $1: 1) ; \mathrm{mp} 82-84{ }^{\circ} \mathrm{C} ;[\alpha]_{\mathrm{D}}:+6.1(\mathrm{c}$ $\left.0.5, \mathrm{CHCl}_{3}\right) ;{ }^{1} \mathrm{H} \mathrm{NMR}\left(600 \mathrm{MHz}, \mathrm{CDCl}_{3}\right) \delta 7.96(\mathrm{~s}, 1 \mathrm{H})$, $7.73(\mathrm{~d}, J=8.3 \mathrm{~Hz}, 2 \mathrm{H}), 7.58(\mathrm{~d}, J=8.3 \mathrm{~Hz}, 2 \mathrm{H}), 6.06$ (d, $J$ $=2.2 \mathrm{~Hz}, \mathrm{H}-1), 5.99$ (br s, H-2), $5.94(\mathrm{~m}, \mathrm{H}-3), 5.38$ (dd, $J$ $=8.8$ and $8.8 \mathrm{~Hz}, \mathrm{H}-4), 4.40(\mathrm{dd}, J=5.2$ and $12.4 \mathrm{~Hz}$, $\mathrm{H}-6), 4.08$ (dd, $J=1.9$ and $12.4 \mathrm{~Hz}, \mathrm{H}-6$ ), 3.94 (m, H-5), $2.19(\mathrm{~s}, 3 \mathrm{H}), 2.08(\mathrm{~s}, 3 \mathrm{H}), 2.07(\mathrm{~s}, 3 \mathrm{H}), 2.06(\mathrm{~s}, 3 \mathrm{H}) ;{ }^{13} \mathrm{C}$ NMR (150 MHz, $\left.\mathrm{CDCl}_{3}\right) \delta 170.5$ (s), 169.7 (s), 169.6 (s), 169.3 (s), 147.3 (s), 132.1 (d, 2C), 128.7 (s), 127.4 (d, 2C), 122.7 (s), 119.8 (d), 83.5 (d, C-1), 72.3 (d, C-5), 68.7 (d, C-3), 68.2 (d, C-2), 66.0 (d, C-4), 61.4 (t, C-6), 20.7 (q), 20.7 (q), 20.7 (q), 20.6 (q); HRMS (ESI) calcd. for $\mathrm{C}_{22} \mathrm{H}_{24} \mathrm{BrN}_{3} \mathrm{O}_{9}\left[\mathrm{M}\left({ }^{79} \mathrm{Br}\right)\right]^{+}$: 553.0696, found: 553.0685; calcd. for $\mathrm{C}_{22} \mathrm{H}_{24} \mathrm{BrN}_{3} \mathrm{O}_{9}\left[\mathrm{M}\left({ }^{81} \mathrm{Br}\right)\right]^{+}$: 555.0649, found:
555.0675. UV ( $\left.\mathrm{CH}_{3} \mathrm{CN}\right) \lambda_{\max }(\varepsilon): 254 \mathrm{~nm}$ (25500); $\mathrm{CD}$ $\left(\mathrm{CH}_{3} \mathrm{CN}\right) \lambda_{\text {ext }}(\Delta \varepsilon): 252(+2.2), 212 \mathrm{~nm}(-2.6)$.

\subsection{1,3,4,6-Tetra- $O$-acetyl-2-azido-2-deoxy-D-gluco- pyranose $(8) .^{17}$}

For the synthesis of this compound glucosamine hydrochloride and $\mathrm{TfN}_{3}$ were required. (a) The triflyl azide was prepared as follows: A suspension of sodium azide (436 mg, $6.7 \mathrm{mmol}$ ) in $8 \mathrm{~mL}$ of pyridine was cooled in ice bath. Then triflic anhydride $(0.94 \mathrm{~mL}, 5.56 \mathrm{mmol})$ was added to the mixture for $5 \mathrm{~min}$ and the reaction kept for $2 \mathrm{~h}$ in ice bath. This $\mathrm{TfN}_{3}$ solution was used in the next step. (b) To a solution of glucosamine hydrochloride (1 g, 4.64 mmol) in $5 \mathrm{~mL}$ of $\mathrm{H}_{2} \mathrm{O}, \mathrm{CuSO}_{4} \cdot 5 \mathrm{H}_{2} \mathrm{O}(11.6 \mathrm{mg}, 0.0464$ mmol) and $\mathrm{Et}_{3} \mathrm{~N}(1.3 \mathrm{~mL}, 9.28 \mathrm{mmol})$ were added while stirring. The mixture was cooled in an ice bath and the above prepared pyridine solution of triflyl azide then added dropwise. The reaction mixture was allowed to warm to room temperature and left for $12 \mathrm{~h}$. The solvent was removed under reduced pressure. (c) The above residue was treated with pyridine $(3 \mathrm{~mL})$, acetic anhydride $(6 \mathrm{~mL})$, and DMAP as catalyst and stirred until completion (TLC). Then the mixture was poured into water and extracted with $\mathrm{CH}_{2} \mathrm{Cl}_{2}$. The combined organic extracts were washed with saturated aqueous $\mathrm{NaHCO}_{3}$ and brine, dried, and concentrated under reduced pressure. The residue was purified by flash column chromatography on silica gel $(n-$ hexane/EtOAc, 6:4) to give compound $\mathbf{8}$ in $98 \%$ yield (1.7 g) as a mixture of anomers $(\alpha: \beta=1: 5)$, NMR data being consistent with those reported in ref. 17 .

\subsection{3,4,6-Tri- $O$-acetyl-1,2-diazido-1,2-deoxy-D-gluco- pyranosides $\left(9\right.$ and 10). ${ }^{16}$}

The 2-azido-2-deoxy- $\beta$-D-glucopyranose 8 (419.4 mg, 1.12 mmol) was allowed to react following Procedure $A$, and the resulting mixture of anomers $(\alpha: \beta, 3: 1)$ was chromatographed on flash silica gel using $n$-hexane/EtOAc (8:2) (1.7 g, 68\% yield).

$\beta$ anomer 9: TLC $\mathrm{R}_{f}=0.45$ (n-hexane/EtOAc, 6:4). $\alpha$ anomer 10: TLC $\mathrm{R}_{f}=0.50$ (n-hexane/EtOAc, 6:4).

Spectroscopic data of these compounds are consistent with those reported in ref. 16 .

\subsection{3,4,6-Tri- $O$-acetyl-1,2-bis-(4-butyl-1H-1,2,3- triazol-1-yl)-1,2-dideoxy- $\beta$-D-glucopyranoside (11a).}

The diazide derivative 9 ( $82 \mathrm{mg}, 0.23 \mathrm{mmol})$ was allowed to react following Procedure $\mathrm{C}$, and taking into account that the quantities must be duplicated, namely $59 \mu \mathrm{L}(0.51$ mmol) of 1-hexyne, $1.7 \mathrm{mg}(0.0069 \mathrm{mmol})$ of $\mathrm{CuSO}_{4} \cdot 5 \mathrm{H}_{2} \mathrm{O}, 19.1 \mathrm{mg}(0.10 \mathrm{mmol})$ of sodium ascorbate, and $2.6 \mathrm{~mL}$ of water. The residue was chromatographed on flash silica gel using $n$-hexane/EtOAc (6:4) (100.5 mg, $84 \%$ yield). TLC $\mathrm{R}_{f}=0.80$ (n-hexane/EtOAc, 6:4); mp $171-172.3{ }^{\circ} \mathrm{C} ;[\alpha]_{\mathrm{D}}:+7.6\left(\mathrm{c} 0.2, \mathrm{CHCl}_{3}\right) ;{ }^{1} \mathrm{H}$ NMR $(500$ $\left.\mathrm{MHz} \mathrm{CDCl}_{3}\right) \delta 7.34(\mathrm{~s}, 1 \mathrm{H}), 7.13(\mathrm{~s}, 1 \mathrm{H}), 6.29(\mathrm{~d}, J=9.5$ $\mathrm{Hz}, \mathrm{H}-1), 5.97$ (dd, $J=9.5$ and $10.5 \mathrm{~Hz}, \mathrm{H}-2), 5.51$ (dd, $J$ 
$=9.8$ and $10.3 \mathrm{~Hz}, \mathrm{H}-3), 5.35(\mathrm{dd}, J=9.6$ and $9.6 \mathrm{~Hz}$, $\mathrm{H}-4) 4.37$ (dd, $J=5.2$ and $13.0 \mathrm{~Hz}, \mathrm{H}-6), 4.21$ (m, H-5 and $\mathrm{H}-6$ '), $2.62(\mathrm{dd}, J=7.6$ and $7.8 \mathrm{~Hz}, 2 \mathrm{H}), 2.56(\mathrm{dd}, J=$ 7.6 and $7.7 \mathrm{~Hz}, 2 \mathrm{H}), 2.09$ (s, 3H), 2.07 (s, 3H), 1.87 (s, 3H), $1.57(\mathrm{~m}, 2 \mathrm{H}), 1.49(\mathrm{~m}, 2 \mathrm{H}), 1.28(\mathrm{~m}, 2 \mathrm{H}), 1.21(\mathrm{~m}, 2 \mathrm{H})$, $0.87(\mathrm{~m}, 6 \mathrm{H}) ;{ }^{13} \mathrm{C} \mathrm{NMR}\left(125 \mathrm{MHz}, \mathrm{CDCl}_{3}\right) \delta 170.5$ (s), 169.5 (s), 168.8 (s), 148.5 (s), 148.1 (s), 122.3 (d), 121.8 (d), $85.1(\mathrm{~d}, \mathrm{C}-1), 74.9$ (d, C-5), $72.7(\mathrm{~d}, \mathrm{C}-2), 68.1$ (d, C-4), $61.6(\mathrm{~d}, \mathrm{C}-3), 61.6(\mathrm{t}, \mathrm{C}-6), 31.1(\mathrm{t}), 31.1(\mathrm{t}), 25.0$ $(\mathrm{t}), 24.9(\mathrm{t}), 22.1(\mathrm{t}), 21.9(\mathrm{t}), 20.7(\mathrm{q}), 20.5(\mathrm{q}), 20.1(\mathrm{q})$, 13.7 (q), 13.7 (q); MS (EI) m/z (rel. intensity) 396 (100); 248 (27), 206 (97); Anal. calcd. for $\mathrm{C}_{24} \mathrm{H}_{36} \mathrm{~N}_{6} \mathrm{O}_{7}$ : C, 55.37; $\mathrm{H}, 6.97 ; \mathrm{N}, 16.14$, found $\mathrm{C}, 55.37 ; \mathrm{H}, 7.29 ; \mathrm{N}, 16.42$; UV $\left(\mathrm{CH}_{3} \mathrm{CN}\right) \lambda_{\max }(\varepsilon): 220 \mathrm{~nm}(7400) ; \mathrm{CD}\left(\mathrm{CH}_{3} \mathrm{CN}\right) \lambda_{\text {ext }}(\Delta \varepsilon)$ : 212 (+2.0), 228 (-1.9), $292 \mathrm{~nm}(+0.2)$.

\subsection{3,4,6-Tri- $O$-acetyl-1,2-dideoxy-1,2-bis-(4- methoxycarbonyl-1H-1,2,3-triazol-1-yl)- $\beta$-D-gluco- pyranoside (11b).}

Prepared from the diazide derivative $9(63 \mathrm{mg}, 0.18 \mathrm{mmol})$ and methyl propiolate $(33.4 \mu \mathrm{L}, 0.4 \mathrm{mmol})$ following Procedure $\mathrm{C}$. The product was chromatographed on flash silica gel using $n$-hexane/EtOAc (6:4) (66 mg, 70\% yield). TLC $\mathrm{R}_{f}=0.15$ (n-hexane/EtOAc, 5:5); mp 225-226 ${ }^{\circ}$; $[\alpha]_{\mathrm{D}}:+22.2\left(\mathrm{c} 0.2, \mathrm{CHCl}_{3}\right) ;{ }^{1} \mathrm{H} \mathrm{NMR}\left(400 \mathrm{MHz}, \mathrm{CDCl}_{3}\right) \delta$ $8.30(\mathrm{~s}, 1 \mathrm{H}), 8.03(\mathrm{~s}, 1 \mathrm{H}), 6.58(\mathrm{~d}, J=9.4 \mathrm{~Hz}, \mathrm{H}-1), 6.03$ (dd, $J=9.9$ and $9.9 \mathrm{~Hz}, \mathrm{H}-3), 5.70(\mathrm{dd}, J=9.9$ and 10.1 $\mathrm{Hz}, \mathrm{H}-2$ ), 5.38 (dd, $J=9.6$ and $9.6 \mathrm{~Hz}, \mathrm{H}-4), 4.33$ (m, H-5 and H-6), 4.24 (d, $J=12.3 \mathrm{~Hz}, \mathrm{H}-6$ '), 3.93 (s, 3H), 3.90 (s, $3 \mathrm{H}), 2.10(\mathrm{~s}, 3 \mathrm{H}), 2.08$ (s, 3H), 1.91 (s, 3H); ${ }^{13} \mathrm{C}$ NMR $(125$ $\mathrm{MHz}, \mathrm{CDCl}_{3}$ ) $\delta 170.4$ (s), 169.4 (s), 169.0 (s), 160.2 (s, 2C), 140.4 (s), 139.9 (s), 129.2 (d), 129.0 (d), 85.0 (d, C-1), 75.3 (d, C-5), 72.5 (d, C-3), 67.9 (d, C-4), 61.9 (d, C-2), 61.3 (t, C-6), 52.4 (q), 52.3 (q), 20.6 (q), 20.5 (q), 20.1 (q); Anal. calcd. for $\mathrm{C}_{20} \mathrm{H}_{24} \mathrm{~N}_{6} \mathrm{O}_{11}: \mathrm{C}, 45.80 ; \mathrm{H}, 4.61 ; \mathrm{N}, 16.02$, found $\mathrm{C}, 46.20 ; \mathrm{H}, 4.79 ; \mathrm{N}, 15.60 ; \mathrm{UV}\left(\mathrm{CH}_{3} \mathrm{CN}\right) \lambda_{\max }(\varepsilon)$ : $211 \mathrm{~nm}(20400) ; \mathrm{CD}\left(\mathrm{CH}_{3} \mathrm{CN}\right) \lambda_{\text {ext }}(\Delta \varepsilon): 216(-4.0), 290$ $\mathrm{nm}(+0.5)$.

\subsection{3,4,6-Tri- $O$-acetyl-1,2-dideoxy-1,2-bis-[4-(4- methylphenyl)-1H-1,2,3-triazol-1-yl]-1,2-dideoxy- $\beta$-D- glucopyranoside (11e).}

Prepared from compound 9 (41 $\mathrm{mg}, 0.12 \mathrm{mmol})$ and 4ethynyl toluene $(33.1 \mu \mathrm{L}, 0.25 \mathrm{mmol})$ following Procedure C $\left(67 \mathrm{mg}, 95 \%\right.$ yield). TLC $\mathrm{R}_{f}=0.33$ ( $n$-hexane/EtOAc, 5:5); mp 304-306.6 ${ }^{\circ} \mathrm{C} \mathrm{dec}$; $[\alpha]_{\mathrm{D}}:+36.3$ (c 0.2, $\left.\mathrm{CHCl}_{3}\right) ;{ }^{1} \mathrm{H}$ NMR $\left(600 \mathrm{MHz}, \mathrm{CDCl}_{3}\right) \delta 8.00(\mathrm{~s}, 1 \mathrm{H}), 7.71(\mathrm{~s}, 1 \mathrm{H}), 7.62$ $(\mathrm{d}, J=7.7 \mathrm{~Hz}, 2 \mathrm{H}), 7.58(\mathrm{~d}, J=7.8 \mathrm{~Hz}, 2 \mathrm{H}), 7.15(\mathrm{~d}, J=$ $7.7 \mathrm{~Hz}, 4 \mathrm{H}), 6.63(\mathrm{~d}, J=9.5 \mathrm{~Hz}, \mathrm{H}-1), 6.18(\mathrm{dd}, J=9.9$ and $10.0 \mathrm{~Hz}, \mathrm{H}-3), 5.75$ (dd, $J=10.0$ and $10.1 \mathrm{~Hz}, \mathrm{H}-2)$, $5.43(\mathrm{dd}, J=9.6$ and $9.7 \mathrm{~Hz}, \mathrm{H}-4), 4.40$ (m, H-5 and $\mathrm{H}-6)$, $4.25(\mathrm{~d}, J=11.3 \mathrm{~Hz}, \mathrm{H}-6 \mathrm{\prime}), 2.33(\mathrm{~s}, 6 \mathrm{H}), 2.09$ (s, 6H), 1.90 $(\mathrm{s}, 3 \mathrm{H}) ;{ }^{13} \mathrm{C} \mathrm{NMR}\left(150 \mathrm{MHz}, \mathrm{CDCl}_{3}\right) \delta 170.5$ (s), 169.6 (s), 169.0 (s), 148.1 (s), 147.6 (s), 138.5 (s, 2C), 129.5 (d, 4C), 126.7 (s, 3C), 125.8 (d, 2C), 125.7 (d, 2C), 121.2 (d), 121.0 (d), $85.0(\mathrm{~d}, \mathrm{C}-1), 74.8(\mathrm{~d}, \mathrm{C}-5$ '), 72.7 (d, C-3), 68.2 (d, C-4), 61.6 (t, C-6), 61.6 (d, C-2), 21.3 (q),21.2 (q), 20.7 (q), 20.5 (q), 20.3 (q); MS (EI) m/z (rel. intensity) 589 $\left([\mathrm{M}+1]^{+}, 11\right) ; 588\left([\mathrm{M}]^{+}, 33\right) ; 430$ (57), 288 (61), 130 (100); HRMS (EI) calcd. for $\mathrm{C}_{30} \mathrm{H}_{32} \mathrm{~N}_{6} \mathrm{O}_{7} \quad[\mathrm{M}]^{+}$: 588.2332, found: 588.2338; Anal. calcd. for $\mathrm{C}_{30} \mathrm{H}_{32} \mathrm{~N}_{6} \mathrm{O}_{7}$ : C, 61.22; $\mathrm{H}$, $5.48 ; \mathrm{N}, 14.28$, found $\mathrm{C}, 61.19 ; \mathrm{H}, 5.58 ; \mathrm{N}, 14.27$; UV $\left(\mathrm{CH}_{3} \mathrm{CN}\right) \lambda_{\max }(\varepsilon): 248 \mathrm{~nm}(34600) ; \mathrm{CD}\left(\mathrm{CH}_{3} \mathrm{CN}\right) \lambda_{\text {ext }}(\Delta \varepsilon)$ : 235 (+2.8), 257 (-8.3), $298 \mathrm{~nm}(+1.2)$.

\subsection{3,4,6-Tri- $O$-acetyl-1,2-bis-[4-(4-bromophenyl)-1H- 1,2,3-triazol-1-yl]-1,2-dideoxy- $\beta$-D-glucopyranoside (11f).}

The diazide derivative 9 (136.5 $\mathrm{mg}, 0.19 \mathrm{mmol})$ and 1 bromo-4-ethynyl benzene $(138.8 \mathrm{mg}, 0.77 \mathrm{mmol})$ were allowed to react following Procedure C $(91.1 \mathrm{mg}, 67 \%$ yield). TLC $\mathrm{R}_{f}=0.49$ ( $n$-hexane/EtOAc, 5:5); mp $290{ }^{\circ} \mathrm{C}$ dec; $[\alpha]_{\mathrm{D}}:-99.1$ (c 0.2 , DMSO); ${ }^{1} \mathrm{H}$ NMR $(500 \mathrm{MHz}$, DMSO-d $\left._{6}\right) \delta 9.14(\mathrm{~s}, 1 \mathrm{H}), 8.80(\mathrm{~s}, 1 \mathrm{H}), 7.70(\mathrm{~m}, 8 \mathrm{H}), 6.99$ $(\mathrm{d}, J=9.8 \mathrm{~Hz}, \mathrm{H}-1), 6.11$ (dd, $J=9.8$ and $9.9 \mathrm{~Hz}, \mathrm{H}-3)$, $5.95(\mathrm{dd}, J=10.0$ and $10.1 \mathrm{~Hz}, \mathrm{H}-2), 5.38(\mathrm{dd}, J=9.7$ and $9.7 \mathrm{~Hz}, \mathrm{H}-4), 4.68$ (ddd, $J=2.0,5.0$ and $10.1 \mathrm{~Hz}, \mathrm{H}-5$ ), $4.32(\mathrm{dd}, J=5.1$ and $12.7 \mathrm{~Hz}, \mathrm{H}-6), 4.21(\mathrm{dd}, J=2.0$ and $12.4 \mathrm{~Hz}, \mathrm{H}-6 \mathrm{\prime}), 2.10$ (s, 3H), 2.08 (s, 3H), 1.89 (s, 3H); ${ }^{13} \mathrm{C}$ NMR (100 MHz, DMSO-d d $\delta 170.9$ (s), 170.3 (s), 169.9 (s), 146.9 (s), 146.3 (s), 132.9 (d, 2C), 132.8 (d, 2C), 130.0 (s), 129.8 (s), 128.1 (d, 2C), 128.0 (d, 2C), 122.4 (s, 2C), 122.2 (d), 121.6 (d), 85.2 (d, C-1), 74.6 (d, C-5), 72.7 (d, C-3), 68.6 (d, C-2), 62.7 (d, C-4), 62.6 (t, C-6), 21.5 (q), $21.3 \quad(\mathrm{q}), \quad 20.8 \quad(\mathrm{q})$; HRMS (ESI) calcd. for $\mathrm{C}_{28} \mathrm{H}_{26} \mathrm{Br}_{2} \mathrm{~N}_{6} \mathrm{O}_{7} \mathrm{Na} \quad\left[\mathrm{M}+\mathrm{Na} \quad\left({ }^{79} \mathrm{Br}\right)_{2}\right]+: \quad 739.0127$, found 739.0117; calcd. for $\mathrm{C}_{28} \mathrm{H}_{26} \mathrm{Br}_{2} \mathrm{~N}_{6} \mathrm{O}_{7} \mathrm{Na}\left[\mathrm{M}+\mathrm{Na}\left({ }^{79} \mathrm{Br}^{81} \mathrm{Br}\right)\right]^{+}$: 741.0107, found 741.0099; calcd. for $\mathrm{C}_{28} \mathrm{H}_{26} \mathrm{Br}_{2} \mathrm{~N}_{6} \mathrm{O}_{7} \mathrm{Na}$ $\left[\mathrm{M}+\mathrm{Na}\left({ }^{81} \mathrm{Br}\right)_{2}\right]^{+}:$743.0086, found 743.0093. Anal. calcd. for $\mathrm{C}_{28} \mathrm{H}_{26} \mathrm{Br}_{2} \mathrm{~N}_{6} \mathrm{O}_{7}$ : $\mathrm{C}, 46.82 ; \mathrm{H}, 3.65 ; \mathrm{N}, 11.70$, found $\mathrm{C}$, 46.93; H, 3.83; N, 11.57; UV $\left(\mathrm{CH}_{3} \mathrm{CN}\right) \lambda_{\max }(\varepsilon): 252 \mathrm{~nm}$ (48000); $\mathrm{CD}\left(\mathrm{CH}_{3} \mathrm{CN}\right) \lambda_{\text {ext }}(\Delta \varepsilon): 239(+3.5), 262$ (-11.3), $296 \mathrm{~nm}(+1.2)$.

\subsection{3,4,6-Tri- $O$-acetyl-1,2-dideoxy-1,2-bis-[4- (methoxy-2-naphthyl)-1H-1,2,3-triazol-1-yl]- $\beta$-D- glucopyranoside (11g).}

Prepared from the diazide derivative $9(12.5 \mathrm{mg}, 0.035$ $\mathrm{mmol}$ ) and 2-ethynyl-6-methoxynaphthalene $(12.8 \mathrm{mg}, 0.7$ mmol) following Procedure C $(22.7 \mathrm{mg}, 90 \%$ yield). TLC $\mathrm{R}_{f}=0.40$ ( $n$-hexane/EtOAc, 5:5); mp 289.8-290 ${ }^{\circ} \mathrm{C} \mathrm{dec}$; $[\alpha]_{\mathrm{D}}:-191.2$ (c 0.2, DMSO); ${ }^{1} \mathrm{H}$ NMR $(600 \mathrm{MHz}, \mathrm{DMSO}-$ d 6 ) $\delta 9.19(\mathrm{~s}, 1 \mathrm{H}), 8.84(\mathrm{~s}, 1 \mathrm{H}), 8.30(\mathrm{~s}, 1 \mathrm{H}), 8.23(\mathrm{~s}, 1 \mathrm{H})$, 7.94-7.83 (m, 6H), 7.37-7.35 (m, 2H), 7.23-7.20 (m, 2H), $7.05(\mathrm{~d}, J=9.7 \mathrm{~Hz}, \mathrm{H}-1), 6.19(\mathrm{dd}, J=9.8$ and $9.8 \mathrm{~Hz}$, $\mathrm{H}-3), 6.02(\mathrm{dd}, J=10.0$ and $10.1 \mathrm{~Hz}, \mathrm{H}-2), 5.42(\mathrm{dd}, J=$ 9.7 and $9.7 \mathrm{~Hz}, \mathrm{H}-4), 4.72(\mathrm{~m}, \mathrm{H}-5), 4.36(\mathrm{dd}, J=5.2$ and $12.7 \mathrm{~Hz}, \mathrm{H}-6), 4.26$ (m, H-6'), 3.92 (s, 3H), 3.91 (s, 3H), $2.12(\mathrm{~s}, 3 \mathrm{H}), 2.10(\mathrm{~s}, 3 \mathrm{H}), 1.91(\mathrm{~s}, 3 \mathrm{H}) ;{ }^{13} \mathrm{C}$ NMR $(150$ MHz, DMSO-d 6 ) $\delta 171.0(\mathrm{~s}), 170.4(\mathrm{~s}), 170.0(\mathrm{~s}), 158.6(\mathrm{~s})$, 158.5 (s), 148.1 (s), 147.6 (s), 135.0 (s), 134.9 (s), 130.5 (d, 2C), 129.3 (s, 2C), 128.5 (d), 128.4 (d), 126.0 (s), 125.8 (s), 124.8 (d), 124.7 (d, 2C), 124.5 (d), 121.5 (d), 121.0 (d), 120.2 (d), 120.1 (d), 107.0 (d), 106.9 (d), 85.3 (d, C-1), 
74.6 (d, C-5), 72.8 (d, C-3), 68.7 (d, C-4), 62.7 (d, C-2), 62.6 (t, C-6), 56.1 (q, 2C), 21.5 (q), 21.3 (q), 20.8 (q); HRMS (ESI) calcd. for $\mathrm{C}_{38} \mathrm{H}_{36} \mathrm{~N}_{6} \mathrm{O}_{9}[\mathrm{M}+\mathrm{Na}]+$ : 743.2441, found: 743.2455; Anal. calcd. for $\mathrm{C}_{38} \mathrm{H}_{36} \mathrm{~N}_{6} \mathrm{O}_{9}$ : C, 63.33; $\mathrm{H}$, $5.03 ; \mathrm{N}, 11.66$, found $\mathrm{C}, 63.66 ; \mathrm{H}, 5.53 ; \mathrm{N}, 11.29 ; \mathrm{UV}$ $\left(\mathrm{CH}_{3} \mathrm{CN}\right) \lambda_{\max }(\varepsilon): 246$ (96000), 255 sh (85800), 289 (24300), 300 (22700), $327 \mathrm{~nm}$ (3200); CD ( $\left.\mathrm{CH}_{3} \mathrm{CN}\right) \lambda_{\text {ext }}$ $(\Delta \varepsilon): 238(+16.7), 255 \mathrm{~nm}(-29.3)$.

\subsection{3,4,6-Tri- $O$-acetyl-1,2-bis-(4-butyl-1H-1,2,3- triazol-1-yl)-1,2-dideoxy- $\alpha$-D-glucopyranoside (12a).}

Prepared from the diazide derivative 10 (100 mg, 0.28 $\mathrm{mmol})$ and 1-hexyne $(72 \mu \mathrm{L}, 0.62 \mathrm{mmol})$ following Procedure C $(88.9 \mathrm{mg}, 61 \%$ yield $)$. TLC $\mathrm{R}_{f}=0.80(n-$ hexane/EtOAc, 6:4); mp 176.6-177.6 ${ }^{\circ} \mathrm{C} ;[\alpha]_{\mathrm{D}}:+141.5$ (c $\left.0.4, \mathrm{CHCl}_{3}\right) ;{ }^{1} \mathrm{H}$ NMR $\left(500 \mathrm{MHz}, \mathrm{CDCl}_{3}\right) \delta 7.13(\mathrm{~s}, 1 \mathrm{H})$, $6.99(\mathrm{~s}, 1 \mathrm{H}), 6.73(\mathrm{dd}, J=8.9$ and $11.3 \mathrm{~Hz}, \mathrm{H}-3$ '), 6.30 (d, $J=6.0 \mathrm{~Hz}, \mathrm{H}-1), 5.54(\mathrm{dd}, J=6.0$ and $11.4 \mathrm{~Hz}, \mathrm{H}-2), 5.40$ (dd, $J=10.1$ and $9.1 \mathrm{~Hz}, \mathrm{H}-4), 4.54(\mathrm{~m}, \mathrm{H}-5), 4.30$ (dd, $J$ $=3.8$ and $12.7 \mathrm{~Hz}, \mathrm{H}-6), 4.08(\mathrm{dd}, J=2.0$ and $12.7 \mathrm{~Hz}$, H-6'), 2.64 (dd, $J=7.6$ and $7.7 \mathrm{~Hz}, 2 \mathrm{H}$ ), 2.49 (dd, $J=7.5$ and $7.6 \mathrm{~Hz}, 2 \mathrm{H}), 2.09(\mathrm{~s}, 3 \mathrm{H}), 2.09(\mathrm{~s}, 3 \mathrm{H}), 1.88(\mathrm{~s}, 3 \mathrm{H})$, $1.57(\mathrm{~m}, 2 \mathrm{H}), 1.42(\mathrm{~m}, 2 \mathrm{H}), 1.31(\mathrm{~m}, 2 \mathrm{H}), 1.17(\mathrm{~m}, 2 \mathrm{H})$, $0.90(\mathrm{dd}, J=7.3$ and $7.4 \mathrm{~Hz}, 3 \mathrm{H}), 0.84(\mathrm{dd}, J=7.3$ and 7.4 $\mathrm{Hz}, 3 \mathrm{H}) ;{ }^{13} \mathrm{C}$ NMR $\left(100 \mathrm{MHz}, \mathrm{CDCl}_{3}\right) \delta 170.4$ (s), 169.7 (s), 169.6 (s), 148.5 (s), 148.5 (s), 123.4 (d), 119.6 (d), 83.3 (d, C-1), 71.5 (d, C-5), 69.1 (d, C-3), 68.5 (d, C-2), 61.2 $(\mathrm{t}, \mathrm{C}-6), 61.0(\mathrm{~d}, \mathrm{C}-4), 31.2(\mathrm{t}), 31.1(\mathrm{t}), 25.0(\mathrm{t}), 24.9(\mathrm{t})$, $22.1(\mathrm{t}), 21.9(\mathrm{t}), 20.7(\mathrm{q}), 20.6(\mathrm{q}), 20.3(\mathrm{q}), 13.7(\mathrm{q}), 13.6$ (q); MS (EI) m/z (rel. intensity) $521([\mathrm{M}+1]+,<1), 433$ (10), 396 (86), 206 (77), 83 (100); Anal. calcd. for $\mathrm{C}_{24} \mathrm{H}_{36} \mathrm{~N}_{6} \mathrm{O}_{7}$ : C, 55.37; $\mathrm{H}, 6.97 ; \mathrm{N}, 16.14$, found $\mathrm{C}, 55.24$; $\mathrm{H}, 7.20 ; \mathrm{N}, 16.37$; UV $\left(\mathrm{CH}_{3} \mathrm{CN}\right) \lambda_{\max }(\varepsilon): 222 \mathrm{~nm}(7400)$; $\mathrm{CD}\left(\mathrm{CH}_{3} \mathrm{CN}\right) \lambda_{\text {ext }}(\Delta \varepsilon): 225(+4.5), 292 \mathrm{~nm}(+0.2)$.

\subsection{3,4,6-Tri- $O$-acetyl-1,2-dideoxy-1,2-bis-(4- methoxycarbonyl-1H-1,2,3-triazol-1-yl)- $\alpha$-D-gluco- pyranoside (12b).}

Compound 10 (120 mg, $0.34 \mathrm{mmol})$ and methyl propiolate $(62.7 \mu \mathrm{L}, 0.75 \mathrm{mmol})$ were allowed to react to yield $12 \mathrm{~b}$ (112.2 mg, 63\%) following Procedure C. TLC $\mathrm{R}_{f}=0.15(n-$ hexane/EtOAc, 5:5); mp 220-221.2 ${ }^{\circ} \mathrm{C}$; $[\alpha]_{\mathrm{D}}:+103.1$ (c 0.2 , $\left.\mathrm{CHCl}_{3}\right) ;{ }^{1} \mathrm{H}$ NMR $\left(600 \mathrm{MHz}, \mathrm{CDCl}_{3}\right) \delta 8.07(\mathrm{~s}, 1 \mathrm{H}), 7.95$ (s, 1H), $6.77(\mathrm{dd}, J=8.9$ and $11.3 \mathrm{~Hz}, \mathrm{H}-3), 6.58(\mathrm{~d}, J=$ $6.0 \mathrm{~Hz}, \mathrm{H}-1), 5.71$ (dd, $J=6.0$ and $11.3 \mathrm{~Hz}, \mathrm{H}-2), 5.44$ (dd, $J=9.1$ and $10.1 \mathrm{~Hz}, \mathrm{H}-4), 4.31$ (dd, $J=4.0$ and 12.7 $\mathrm{Hz}, \mathrm{H}-6), 4.26$ (m, H-5) $4.06(\mathrm{dd}, J=1.8$ and $12.7 \mathrm{~Hz}$, H-6), 3.93 (s, 3H), 3.87 (s, 3H), 2.11 (s, 3H), 2.09 (s, 3H), $1.94(\mathrm{~s}, 3 \mathrm{H}) ;{ }^{13} \mathrm{C}$ NMR $\left(150 \mathrm{MHz}, \mathrm{CDCl}_{3}\right) \delta 170.3(\mathrm{~s})$, 169.8 (s), 169.4 (s), 160.0 (s), 159.9 (s), 140.5 (s), 140.0 (s), 129.9 (d), 126.5 (d), 83.7 (d, C-1), 71.6 (d, C-5), 68.8 (d, C-3), 68.1 (d, C-4), 61.0 (t, C-6), 61.3 (d, C-2), 52.6 (q), 52.3 (q), 20.6 (q), 20.5 (q), 20.4 (q); MS (EI) m/z (rel. intensity) $525\left([\mathrm{M}+1]^{+}, 3\right), 465(56), 207$ (63), 180 (76), 139 (73), 97.0 (100); HRMS (EI) calcd. for $\mathrm{C}_{20} \mathrm{H}_{25} \mathrm{~N}_{6} \mathrm{O} 11$ $[\mathrm{M}+1]^{+}$: 525.1581, found: 525.1602; Anal. calcd. for $\mathrm{C}_{20} \mathrm{H}_{24} \mathrm{~N}_{6} \mathrm{O}_{11}$ : C, 45.80; H, 4.61; N, 16.02, found C, 46.06;
$\mathrm{H}, 4.77 ; \mathrm{N}, 15.63 ; \mathrm{UV}\left(\mathrm{CH}_{3} \mathrm{CN}\right) \lambda_{\max }(\varepsilon): 211 \mathrm{~nm}(20400)$; $\mathrm{CD}\left(\mathrm{CH}_{3} \mathrm{CN}\right) \lambda_{\text {ext }}(\Delta \varepsilon): 211(+4.2), 226(-1.4), 292 \mathrm{~nm}$ $(+0.5)$.

\subsection{3,4,6-Tri- $O$-acetyl-1,2-dideoxy-1,2-bis-[4-(4- methylphenyl)-1H-1,2,3-triazol-1-yl]- $\alpha$-D-gluco- pyranoside (12e).}

Prepared from compound $\mathbf{1 0}(100 \mathrm{mg}, 0.28 \mathrm{mmol})$ and 4ethynyl toluene $(81 \mu \mathrm{L}, 0.62 \mathrm{mmol})$ according to Procedure C (158.1 mg, 96\% yield). TLC R $\mathrm{R}_{f}=0.33$ ( $n$-hexane/EtOAc, 5:5); mp 264-266 ${ }^{\circ} \mathrm{C} \mathrm{dec} ;[\alpha]_{\mathrm{D}}:+77.6\left(\right.$ c $\left.0.6, \mathrm{CHCl}_{3}\right) ;{ }^{1} \mathrm{H}$ NMR $\left(500 \mathrm{MHz}, \mathrm{CDCl}_{3}\right) \delta 7.69(\mathrm{~s}, 1 \mathrm{H}), 7.61(\mathrm{~s}, 1 \mathrm{H}), 7.60$ $(\mathrm{d}, J=8.2 \mathrm{~Hz}, 2 \mathrm{H}), 7.49(\mathrm{~d}, J=8.0 \mathrm{~Hz}, 2 \mathrm{H}), 7.19(\mathrm{~d}, J=$ $7.9 \mathrm{~Hz}, 2 \mathrm{H}), 7.11(\mathrm{~d}, J=7.9 \mathrm{~Hz}, 2 \mathrm{H}), 6.91(\mathrm{dd}, J=8.9$ and $11.3 \mathrm{~Hz}, \mathrm{H}-3), 6.52$ (d, $J=5.9 \mathrm{~Hz}, \mathrm{H}-1), 5.69$ (dd, $J=5.9$ and $11.4 \mathrm{~Hz}, \mathrm{H}-2), 5.46$ (dd, $J=9.2$ and $9.9 \mathrm{~Hz}, \mathrm{H}-4)$, $4.47(\mathrm{~m}, \mathrm{H}-5), 4.33$ (dd, $J=3.8$ and $12.7 \mathrm{~Hz}, \mathrm{H}-6), 4.10$ (dd, $J=1.8$ and $12.7 \mathrm{~Hz}, \mathrm{H}-6$ '), 2.35 (s, 3H), 2.30 (s, 3H), $2.11(\mathrm{~s}, 3 \mathrm{H}), 2.10(\mathrm{~m}, 3 \mathrm{H}), 1.90(\mathrm{~s}, 3 \mathrm{H}) ;{ }^{13} \mathrm{C} \mathrm{NMR}(100$ $\left.\mathrm{MHz}, \mathrm{CDCl}_{3}\right) \delta 170.4(\mathrm{~s}), 169.8$ (s), 169.5 (s), 148.2 (s), 148.1 (s), 138.8 (s), 138.3 (s), 129.6 (d, 2C), 129.4 (d, 2C), 126.8 (s), 126.2 (s), 125.7 (d, 4C), 121.9 (d), 118.3 (d), 83.5 (d, C-1), 71.4 (d, C-5), 69.2 (d, C-3), 68.5 (d, C-4), 61.2 (t, C-6), 61.1 (d, C-2), 21.2 (q, 2C), 20.6 (q), 20.5 (q), 20.4 (q); MS (EI) m/z (rel. intensity) 589 ([M+1] $\left.]^{+}, 14\right), 588$ $\left([\mathrm{M}]^{+}, 37\right), 430$ (10), 288 (100), 130 (66); HRMS (EI) calcd. for $\mathrm{C}_{30} \mathrm{H}_{32} \mathrm{~N}_{6} \mathrm{O}_{7}[\mathrm{M}]^{+}$: 588.2332, found: 588.2338; Anal. calcd. for $\mathrm{C}_{30} \mathrm{H}_{32} \mathrm{~N}_{6} \mathrm{O}_{7}$ : C, 61.22; H, 5.48; N, 14.28, found $\mathrm{C}, 61.35 ; \mathrm{H}, 5.28 ; \mathrm{N}, 14.17 ; \mathrm{UV}\left(\mathrm{CH}_{3} \mathrm{CN}\right) \lambda_{\max }(\varepsilon)$ : $246 \mathrm{~nm}(34600) ; \mathrm{CD}\left(\mathrm{CH}_{3} \mathrm{CN}\right) \lambda_{\mathrm{ext}}(\Delta \varepsilon): 236(+6.2), 255$ (-11.2), $296 \mathrm{~nm}(+1.1)$.

\subsection{3,4,6-Tri- $O$-acetyl-1,2-bis-[4-(4-bromophenyl)-1H- 1,2,3-triazol-1-yl]-1,2-dideoxy- $\alpha$-D-glucopyranoside (12f).}

Following Procedure C compound $10(900 \mathrm{mg}, 2.5 \mathrm{mmol})$ and 1-bromo-4-ethynyl benzene (961.5 mg, $5.3 \mathrm{mmol}$ ) were allowed to react to give $\mathbf{1 2 f}(1.3 \mathrm{~g}, 72 \%)$. TLC $\mathrm{R}_{f}=$ 0.49 (n-hexane/EtOAc, 5:5); $\mathrm{mp} 290.6^{\circ} \mathrm{C} \mathrm{dec} ;[\alpha]_{\mathrm{D}}:+90.5$ (c 0.2, DMSO); ${ }^{1} \mathrm{H}$ NMR (500 MHz, $\left.\mathrm{CDCl}_{3}\right) \delta 7.70(\mathrm{~s}, 1 \mathrm{H})$, $7.67(\mathrm{~s}, 1 \mathrm{H}), 7.59(\mathrm{~d}, J=8.5 \mathrm{~Hz}, 2 \mathrm{H}), 7.56(\mathrm{~d}, J=8.5 \mathrm{~Hz}$, $2 \mathrm{H}), 7.46(\mathrm{~d}, J=8.6 \mathrm{~Hz}, 4 \mathrm{H}), 6.88(\mathrm{dd}, J=8.9$ and 11.3 $\mathrm{Hz}, \mathrm{H}-3), 6.51(\mathrm{~d}, J=5.9 \mathrm{~Hz}, \mathrm{H}-1), 5.69$ (dd, $J=5.9$ and $11.4 \mathrm{~Hz}, \mathrm{H}-2), 5.47$ (dd, $J=9.4$ and $9.7 \mathrm{~Hz}, \mathrm{H}-4), 4.43$ (d, $J=10.1 \mathrm{~Hz}, \mathrm{H}-5), 4.33(\mathrm{dd}, J=3.8$ and $12.7 \mathrm{~Hz}, \mathrm{H}-6)$, 4.11 (dd, $J=1.9$ and $12.7 \mathrm{~Hz}, \mathrm{H}-6$ '), 2.12 (s, 3H), 2.10 (s, $3 \mathrm{H}), 1.92$ (s, 3H); ${ }^{13} \mathrm{C}$ NMR (125 MHz, $\left.\mathrm{CDCl}_{3}\right) \delta 170.4$ (s), 169.9 (s), 169.5 (s), 147.2 (s), 147.1 (s), 132.2 (d, 2C), 132.0 (d, 2C), $128.4(\mathrm{~s}), 127.8(\mathrm{~s}), 127.3$ (d, 2C), $127.2(\mathrm{~d}$, 2C), 123.0 (s), 122.5 (s), 122.2 (d), 118.8 (d), 83.7 (d, C-1), 71.5 (d, C-5), 69.0 (d, C-3), 68.3 (d, C-4), 61.1 (d, C-2), 61.0 (t, C-6), 20.7 (q), 20.6 (q), 20.5 (q); HRMS (ESI) calcd. for $\mathrm{C}_{28} \mathrm{H}_{26} \mathrm{Br}_{2} \mathrm{~N}_{6} \mathrm{O}_{7} \mathrm{Na}\left[\mathrm{M}+\mathrm{Na}\left({ }^{79} \mathrm{Br}\right)_{2}\right]^{+}$: 739.0127, found 739.0123; calcd. for $\mathrm{C}_{28} \mathrm{H}_{26} \mathrm{Br}_{2} \mathrm{~N}_{6} \mathrm{O}_{7} \mathrm{Na}[\mathrm{M}+\mathrm{Na}$ $\left.\left({ }^{79} \mathrm{Br}^{81} \mathrm{Br}\right)\right]^{+}$: 741.0107, found 741.0104; calcd. for $\mathrm{C}_{28} \mathrm{H}_{26} \mathrm{Br}_{2} \mathrm{~N}_{6} \mathrm{O}_{7} \mathrm{Na} \quad\left[\mathrm{M}+\mathrm{Na} \quad\left({ }^{81} \mathrm{Br}\right)_{2}\right]^{+}: \quad 743.0086$, found 743.0093. Anal. calcd. for $\mathrm{C}_{28} \mathrm{H}_{26} \mathrm{Br}_{2} \mathrm{~N}_{6} \mathrm{O}_{7}: \mathrm{C}, 46.82 ; \mathrm{H}$, 
3.65; N, 11.70, found $\mathrm{C}, 46.79 ; \mathrm{H}, 3.93 ; \mathrm{N}, 11.71 ; \mathrm{UV}$ $\left(\mathrm{CH}_{3} \mathrm{CN}\right) \lambda_{\max }(\varepsilon): 252 \mathrm{~nm}(48000) ; \mathrm{CD}\left(\mathrm{CH}_{3} \mathrm{CN}\right) \lambda_{\text {ext }}(\Delta \varepsilon)$ : $241(+9.3), 260(-14.5), 293 \mathrm{~nm}(+2.0)$.

\subsection{3,4,6-Tri- $O$-acetyl-1,2-dideoxy-1,2-bis-[4- (methoxy-2-naphthyl)-1H-1,2,3-triazol-1-yl]- $\alpha$-D- glucopyranoside (12g).}

Prepared from compound $\mathbf{1 0}(25.5 \mathrm{mg}, 0.072 \mathrm{mmol})$ and 2ethynyl-6-methoxynaphthalene $(26.1 \mathrm{mg}, 0.14 \mathrm{mmol})$ following Procedure C ( $29 \mathrm{mg}, 56 \%$ yield). TLC $\mathrm{R}_{f}=0.40$ (n-hexane/EtOAc, 5:5); mp 289-290 ${ }^{\circ} \mathrm{C} \mathrm{dec;}[\alpha]_{\mathrm{D}}:+101.1$ (c 0.1, DMSO); ${ }^{1} \mathrm{H}$ NMR $\left(600 \mathrm{MHz}, \mathrm{DMSO}-\mathrm{d}_{6}\right) \delta 8.68(\mathrm{~s}$, $1 \mathrm{H}), 8.29$ (s, 1H), $8.19(\mathrm{~s}, 1 \mathrm{H}), 8.13(\mathrm{~s}, 1 \mathrm{H}), 7.89-7.73(\mathrm{~m}$, $6 \mathrm{H}), 7.35(\mathrm{~d}, J=2.4 \mathrm{~Hz}, 1 \mathrm{H}), 7.31(\mathrm{~d}, J=2.3 \mathrm{~Hz}, 1 \mathrm{H}), 7.20$ (dd, $J=2.5$ and $9.0 \mathrm{~Hz}, 1 \mathrm{H}), 7.16(\mathrm{dd}, J=2.5$ and $8.9 \mathrm{~Hz}$, $1 \mathrm{H}), 7.02(\mathrm{~d}, J=5.6, \mathrm{H}-1), 6.87(\mathrm{dd}, J=9.1$ and $11.2 \mathrm{~Hz}$, $\mathrm{H}-3), 6.11(\mathrm{dd}, J=5.5$ and $11.3 \mathrm{~Hz}, \mathrm{H}-2), 5.50(\mathrm{dd}, J=9.6$ and $9.8 \mathrm{~Hz}, \mathrm{H}-4), 4.72(\mathrm{~m}, \mathrm{H}-5), 4.34(\mathrm{dd}, J=4.5$ and 12.8 $\mathrm{Hz}, \mathrm{H}-6$ ), 4.17 (dd, $J=2.2$ and $12.7 \mathrm{~Hz}, \mathrm{H}-6), 3.90$ (s, 3H), 3.89 (s, 3H), 2.14 (s, 3H), 2.08 (s, 3H), 1.90 (s, 3H); ${ }^{13} \mathrm{C}$ NMR (150 MHz, DMSO-d $) \delta 170.9(\mathrm{~s}), 170.4(\mathrm{~s})$, $170.2(\mathrm{~s}), 158.5$ (s, 2C), $147.2(\mathrm{~s}), 147.1$ (s), 135.0 (s), 134.9 (s), 130.5 (d), 130.4 (d), 129.3 (s), 129.2 (s), 128.4 (d), 128.3 (d), 125.9 (s), 125.7 (s), 124.9 (d), 124.8 (d), 124.7 (d, 2C), 124.5 (d), 121.5 (d), 120.1 (d, 2C), 106.9 (d, 2C), 83.4 (d, C-1), 72.5 (d, C-5), 69.8 (d, C-3), 69.5 (d, C-4), 62.5 (t, C-6), 60.6 (d, C-2), 56.1 (q, 2C), 21.5 (q), 21.4 (q), 21.1 (q); HRMS (ESI) calcd. for $\mathrm{C}_{38} \mathrm{H}_{36} \mathrm{~N}_{6} \mathrm{O}_{9} \mathrm{Na}$ $[\mathrm{M}+\mathrm{Na}]^{+}$: 743.2441, found: 743.2431; Anal. calcd. for $\mathrm{C}_{38} \mathrm{H}_{36} \mathrm{~N}_{6} \mathrm{O}_{9}$ : C, 63.33; H, 5.03; N, 11.66, found $\mathrm{C}$, 63.65; $\mathrm{H}, 5.301 ; \mathrm{N}, 11.29 ; \mathrm{UV}\left(\mathrm{CH}_{3} \mathrm{CN}\right) \lambda_{\max }(\varepsilon): 245$ (96000), 255 sh (78000), 289 (23000), 300 (21300), 327 nm (3200); $\mathrm{CD}\left(\mathrm{CH}_{3} \mathrm{CN}\right) \lambda_{\text {ext }}(\Delta \varepsilon): 234(+53.8), 255 \mathrm{~nm}(-69.3)$.

\subsection{1,2-Bis-[4-(4-bromophenyl)-1H-1,2,3-triazol-1-yl]-} 1,2-dideoxy- $\beta$-D-glucopyranoside (13f).

To a solution of compound $\mathbf{1 1 f}(50.9 \mathrm{mg}, 0.071 \mathrm{mmol})$ in $\mathrm{CH}_{2} \mathrm{Cl}_{2} \quad(0.35 \mathrm{~mL}), \mathrm{MeOH}(0.71 \mathrm{~mL})$ and sodium methoxide $(11.5 \mathrm{mg}, 0.21 \mathrm{mmol})$ were added following Procedure D, giving 13f $\left(40.2 \mathrm{mg}, 96 \%\right.$ yield). TLC $\mathrm{R}_{f}=$ $0.20\left(\mathrm{CH}_{2} \mathrm{Cl}_{2} / \mathrm{MeOH} 95: 5\right) ; \mathrm{mp} 298-301{ }^{\circ} \mathrm{C}$, dec; $[\alpha]_{\mathrm{D}}$ : -124.2 (c 0.4, DMSO); ${ }^{1} \mathrm{H}$ NMR (500 MHz, DMSO-d 6 ) $\delta$ $9.07(\mathrm{~s}, 1 \mathrm{H}), 8.76(\mathrm{~s}, 1 \mathrm{H}), 7.78-7.67(\mathrm{~m}, 8 \mathrm{H}), 6.56(\mathrm{~d}, J=$ $9.8 \mathrm{~Hz}, \mathrm{H}-1), 5.87$ (d, $J=5.7 \mathrm{~Hz}, \mathrm{OH}), 5.66(\mathrm{~d}, J=5.5 \mathrm{~Hz}$, $\mathrm{OH}), 5.21(\mathrm{dd}, J=10.1$ and $10.1 \mathrm{~Hz}, \mathrm{H}-2), 4.82(\mathrm{dd}, J=$ 5.9 and $5.8 \mathrm{~Hz}, \mathrm{OH}), 4.24(\mathrm{~m}, \mathrm{H}-3), 3.84(\mathrm{~m}, 2 \mathrm{H}), 3.63$ (m, $\mathrm{H}-6$ '), 3.58 (m, H-4); ${ }^{13} \mathrm{C}$ NMR (125 MHz, DMSO-d 6 ) $\delta$ 146.5 (s), 145.8 (s), 132.9 (d, 2C), 132.8 (d, 2C), 130.5 (s), $130.2(\mathrm{~s}), 128.1(\mathrm{~d}, 2 \mathrm{C}), 127.9(\mathrm{~d}, 2 \mathrm{C}), 122.6(\mathrm{~s}), 122.2(\mathrm{~s})$, 121.9 (d), 121.8 (d), 86.1 (d, C-1'), 81.2 (d, C-5'), 75.0 (d, C-3'), 70.8 (d, C-4'), 65.9 (d, C-2'), 61.4 (t, C-6'); Anal. calcd. for $\mathrm{C}_{22} \mathrm{H}_{20} \mathrm{Br}_{2} \mathrm{~N}_{6} \mathrm{O}_{4}$ : C, 44.62; $\mathrm{H}, 3.40 ; \mathrm{N}, 14.19$, found $\mathrm{C}, 44.98 ; \mathrm{H}, 3.50 ; \mathrm{N}, 13.90 ; \mathrm{UV}\left(\mathrm{CH}_{3} \mathrm{CN}\right) \lambda_{\max }(\varepsilon)$ : $252 \mathrm{~nm}(48000) ; \mathrm{CD}\left(\mathrm{CH}_{3} \mathrm{CN}\right) \lambda_{\text {ext }}(\Delta \varepsilon): 242(+4.7), 263$ (-18.1), $297 \mathrm{~nm}(+1.7)$.
4.35. 1,2-Bis-[4-(4-bromophenyl)-1H-1,2,3-triazol-1-yl]1,2-dideoxy- $\alpha$-D-glucopyranoside (14f).

Prepared from compound $\mathbf{1 2 f}(274 \mathrm{mg}, 0.38 \mathrm{mmol})$ and sodium methoxide (61.6 $\mathrm{mg}, 1.14 \mathrm{mmol})$ following Procedure D (172.6 mg, 77\% yield). TLC $\mathrm{R}_{f}=0.20$ $\left(\mathrm{CH}_{2} \mathrm{Cl}_{2} / \mathrm{MeOH}\right.$ 95:5); $[\alpha]_{\mathrm{D}}:+28.0$ (c 0.7, DMSO); ${ }^{1} \mathrm{H}$ NMR (600 MHz, DMSO-d $) \delta 8.70(\mathrm{~s}, 1 \mathrm{H}), 8.52$ (brs, OH), 8.44 (s, 1H), 7.76-7.60 (m, 8H), 6.78 (d, $J=5.9 \mathrm{~Hz}, \mathrm{H}-1)$, 6.42 (brs, OH), 5.27 (dd, $J=5.8$ and $10.9 \mathrm{~Hz}, \mathrm{H}-2), 5.06$ (dd, $J=8.8$ and $10.7 \mathrm{~Hz}, \mathrm{H}-3$ ), 4.94 (brs, OH), 3.92 (dd, $J$ $=3.7$ and $10.0 \mathrm{~Hz} \mathrm{H}-5), 3.68(\mathrm{~m}, 3 \mathrm{H}) ;{ }^{13} \mathrm{C} \mathrm{NMR}(150$ MHz, DMSO-d 6 ) $\delta 145.3$ (s), 145.2 (s), 132.5 (d, 2C), 132.4 (d, 2C), 129.7 (s), 129.2 (s), 127.7 (d, 2C), 127.5 (d, 2C), 124.1 (s), 121.9 (s), 121.8 (d), 121.6 (d), 84.1 (d, C-1), 77.5 (d), 70.7 (d), 69.8 (d), 63.3 (d), 61.0 (t, C-6); MS (EI) $\mathrm{m} / \mathrm{z}$ (rel. intensity) 594:592:590 $\left([\mathrm{M}+1]^{+}, 2: 4: 1\right), 418(14)$, 226 (17), 225 (100), 223 (83); Anal. calcd. for $\mathrm{C}_{22} \mathrm{H}_{20} \mathrm{Br}_{2} \mathrm{~N}_{6} \mathrm{O}_{4}$ : C, 44.62; H, 3.40; N, 14.19; found $\mathrm{C}$, 44.62; H, 3.40; N, 14.46; UV $\left(\mathrm{CH}_{3} \mathrm{CN}\right) \lambda \max (\varepsilon): 253 \mathrm{~nm}$ (48000); $\mathrm{CD}\left(\mathrm{CH}_{3} \mathrm{CN}\right) \lambda_{\text {ext }}(\Delta \varepsilon): 242(+8.9), 261(-26.5)$, $299 \mathrm{~nm}(+1.1)$.

\subsection{6. $(1 R, 2 R)$-1,2-Diazidocyclohexane $(15) .^{31}$}

For the synthesis of this compound $(1 R, 2 R)-(-)-1,2-$ diaminocyclohexane and $\mathrm{TfN}_{3}$ were required. (a) The triflyl azide was prepared as follows: After sodium azide (632 $\mathrm{mg}, 9.72 \mathrm{mmol})$ was dissolved in water $(1.6 \mathrm{~mL})$, toluene $(1.6 \mathrm{~mL})$ was added. The mixture was cooled to $0{ }^{\circ} \mathrm{C}$ under vigorous stirring. After the dropwise addition of triflic anhydride $(0.82 \mathrm{~mL}, 4.9 \mathrm{mmol})$ and further vigorous stirring for $30 \mathrm{~min}$ at $0{ }^{\circ} \mathrm{C}$, the temperature was raised to 10 ${ }^{\circ} \mathrm{C}$ and the biphasic mixture was stirred for $2 \mathrm{~h}$. A saturated aqueous solution of $\mathrm{NaHCO}_{3}$ was added dropwise until gas evolution had ceased. The two phases were separated and the aqueous layer was extracted with toluene $(2 \times 1.6 \mathrm{~mL})$. The combined organic layers were used in the next step.

(b) To a solution of $(1 R, 2 R)$-(-)-1,2-diaminocyclohexane (100 mg, $0.88 \mathrm{mmol}$ ) in $2.3 \mathrm{~mL}$ of $\mathrm{H}_{2} \mathrm{O}, \mathrm{CuSO}_{4} \cdot 5 \mathrm{H}_{2} \mathrm{O}(19.1$ $\mathrm{mg}, 0.077 \mathrm{mmol})$ and $\mathrm{NaHCO}_{3}(598 \mathrm{mg}, 7.12 \mathrm{mmol})$ were added while stirring. The mixture was cooled in an ice bath and the above prepared solution of triflyl azide then added dropwise. The reaction mixture was allowed to warm to room temperature and left for $15 \mathrm{~h}$. The solvent was removed under reduced pressure. The residue was purified by flash column chromatography on silica gel ( $n$ hexane/EtOAc, 9.5:0.5) (102.3 mg, 70\% yield). TLC $\mathrm{R}_{f}=$ 0.20 (n-hexane/EtOAc, 9:1); yellow oil; ${ }^{1} \mathrm{H}$ NMR (400 $\left.\mathrm{MHz}, \mathrm{CDCl}_{3}\right) \delta 3.19(\mathrm{~m}, 2 \mathrm{H}), 2.05(\mathrm{~m}, 2 \mathrm{H}), 1.76(\mathrm{~m}, 2 \mathrm{H})$, 1.33-1.27 (m, 4H); $\left.{ }^{13} \mathrm{C} \mathrm{NMR} \mathrm{(100} \mathrm{MHz,} \mathrm{CDCl}_{3}\right) \delta 64.4(\mathrm{~d}$, 2C), $30.5(\mathrm{t}, 2 \mathrm{C}), 23.7(\mathrm{t}, 2 \mathrm{C})$.

\subsection{7. (1R,2R)-1,2-Bis(4-(4-bromophenyl)-1H-1,2,3- triazol-1-yl)-cyclohexane (16f).}

Prepared from compound $15(517 \mathrm{mg}, 3.11 \mathrm{mmol})$ and 1bromo-4-ethynyl benzene $(1.24 \mathrm{~g}, 6.85 \mathrm{mmol})$ following Procedure C (1.3 g, 81\% yield). TLC $\mathrm{R}_{f}=0.46(n-$ hexane/EtOAc, 5:5); mp 319-320 ${ }^{\circ} \mathrm{C}$; $[\alpha]_{\mathrm{D}}:-225.7$ (c 0.2, 
$\left.\mathrm{CHCl}_{3}\right) ;{ }^{1} \mathrm{H}$ NMR $\left(500 \mathrm{MHz}, \mathrm{CDCl}_{3}\right) \delta 7.48(\mathrm{~m}, 8 \mathrm{H}), 7.41$ (s, 2H), $4.98(\mathrm{~m}, 2 \mathrm{H}), 2.39(\mathrm{~m}, 4 \mathrm{H}), 2.11(\mathrm{~m}, 2 \mathrm{H}), 1.67(\mathrm{~m}$, $2 \mathrm{H}) ;{ }^{13} \mathrm{C} \mathrm{NMR}\left(100 \mathrm{MHz}, \mathrm{CDCl}_{3}\right) \delta 146.2(\mathrm{~s}, 2 \mathrm{C}), 131.9$ (d, 4C), 129.0 (s, 2C), 127.1 (d, 4C), 122.2 (s, 2C), 120.4 (d, 2C), 64.0 (d, 2C), 32.8 (t, 2C), 24.5 (t, 2C); HRMS (ESI) calcd. for $\mathrm{C}_{22} \mathrm{H}_{20} \mathrm{Br}_{2} \mathrm{~N}_{6} \mathrm{Na}\left[\mathrm{M}+\mathrm{Na}\left({ }^{79} \mathrm{Br}\right)_{2}\right]^{+}: 549.0014$, found 549.0009; calcd. for $\mathrm{C}_{22} \mathrm{H}_{20} \mathrm{Br}_{2} \mathrm{~N}_{6} \mathrm{Na}$ $\left[\mathrm{M}+\mathrm{Na}\left({ }^{79} \mathrm{Br}^{81} \mathrm{Br}\right)\right]^{+}$: 550.9993, found 550.9986; calcd. for $\mathrm{C}_{22} \mathrm{H}_{20} \mathrm{Br}_{2} \mathrm{~N}_{6} \mathrm{Na} \quad\left[\mathrm{M}+\mathrm{Na}\left({ }^{81} \mathrm{Br}\right)_{2}\right]^{+}:$552.9973, found 552.9993; Anal. calcd. for $\mathrm{C}_{22} \mathrm{H}_{20} \mathrm{Br}_{2} \mathrm{~N}_{6}$ : C, 50.02; H, 3.82; $\mathrm{N}, 15.91$, found $\mathrm{C}, 50.01 ; \mathrm{H}, 4.035 ; \mathrm{N}, 16.05 ; \mathrm{UV}\left(\mathrm{CH}_{3} \mathrm{CN}\right)$ $\lambda_{\max }(\varepsilon): 252 \mathrm{~nm}(48000) ; \mathrm{CD}\left(\mathrm{CH}_{3} \mathrm{CN}\right) \lambda_{\text {ext }}(\Delta \varepsilon): 263$ $(-20.9), 241 \mathrm{~nm}(+4.1)$.

4.38. $\quad(1 R, 2 R)-1,2-B i s(4-(b i p h e n y l-4-o l)-1,2,3-t r i a z o l-1-$ yl)-cyclohexane (17).

A mixture of $\mathrm{Pd}(\mathrm{OAc})_{2}(1.3 \mathrm{mg}, 0.006 \mathrm{mmol})$ and triphenylphosphine $(7.5 \mathrm{mg}, 0.029 \mathrm{mmol})$ was dissolved in DMSO $(0.5 \mathrm{~mL})$. Then, compound $16 \mathbf{f}(50 \mathrm{mg}, 0.095$ mmol), an aqueous $2 \mathrm{M}$ solution of $\mathrm{Na}_{2} \mathrm{CO}_{3}(0.23 \mathrm{~mL})$, and 4-hydroxy-phenylboronic acid (16.5 $\mathrm{mg}, 0.12 \mathrm{mmol})$ were sequentially added. The resulting mixture was exposed to microwave irradiation $(5 \mathrm{~min}, 650 \mathrm{~W})$. After being cooled to RT the mixture was diluted with water and extracted with $\mathrm{CH}_{2} \mathrm{Cl}_{2}$. The combined organic phase were dried and concentrated. The crude product was purified by flash column chromatography on silica gel ( $n$ hexane/EtOAc/DMSO 2.5:7:0.5) to give 17 in 74\% yield $(39 \mathrm{mg})$. TLC $\mathrm{R}_{f}=0.16 \quad(n$-hexane/EtOAc/DMSO, 2.5:7:0.5); mp 305-307 ${ }^{\circ} \mathrm{C}$ dec; $[\alpha]_{\mathrm{D}}:-241.1$ (c 0.1, DMSO); ${ }^{1} \mathrm{H}$ NMR (500 MHz, DMSO-d 6 ) $\delta 9.59$ (brs, $2 \mathrm{H}$ ), $8.64(\mathrm{~s}, 2 \mathrm{H}), 7.79$ (d, $J=8.4 \mathrm{~Hz}, 4 \mathrm{H}), 7.66(\mathrm{~d}, J=8.4 \mathrm{~Hz}$, $4 \mathrm{H}), 7.54(\mathrm{~d}, J=8.7 \mathrm{~Hz}, 4 \mathrm{H}), 6.87(\mathrm{~d}, J=8.6 \mathrm{~Hz}, 4 \mathrm{H})$, $5.20(\mathrm{~m}, 2 \mathrm{H}), 2.32(\mathrm{~m}, 2 \mathrm{H}), 2.24(\mathrm{~m}, 2 \mathrm{H}), 2.02(\mathrm{~m}, 2 \mathrm{H})$, $1.70(\mathrm{~m}, 2 \mathrm{H}) ;{ }^{13} \mathrm{C}$ NMR $\left(150 \mathrm{MHz}, \mathrm{DMSO}-\mathrm{d}_{6}\right) \delta 158.3(\mathrm{~s}$, 2C), $146.9(\mathrm{~s}, 2 \mathrm{C}), 140.6(\mathrm{~s}, 2 \mathrm{C}), 131.3(\mathrm{~s}, 2 \mathrm{C}), 129.6(\mathrm{~s}$ 2C), 128.7 (d, 8C), 127.4 (d, 4C), 126.6 (d, 4C), 116.8 (d, 2C), 63.9 (d, 2C), $33.4(\mathrm{t}, 2 \mathrm{C}), 25.1(\mathrm{t}, 2 \mathrm{C}) . \mathrm{MS}(\mathrm{EI}) \mathrm{m} / \mathrm{z}$ (rel. intensity) $554.2\left(\mathrm{M}^{+}, 25\right), 462.2\left(\mathrm{M}^{+}-\mathrm{C}_{6} \mathrm{H}_{5} \mathrm{O}, 24\right), 57.1$ (100). HRMS (EI) calcd. for $\mathrm{C}_{34} \mathrm{H}_{30} \mathrm{~N}_{6} \mathrm{O}_{2}[\mathrm{M}]^{+}:$554.2430, found: 554.2439; $\mathrm{UV}\left(\mathrm{CH}_{3} \mathrm{CN}\right) \lambda_{\max }(\varepsilon): 285 \mathrm{~nm}(70000)$; $\mathrm{CD}\left(\mathrm{CH}_{3} \mathrm{CN}\right) \lambda_{\text {ext }}(\Delta \varepsilon): 298$ (-19.9), $228 \mathrm{~nm}(-6.8)$.

\subsection{3,4,6-Tri- $O$-acetyl-2-azido-1- $O$-(4-bromobenzoyl)- 2-deoxy- $\beta$-D-glucopyranoside (18) and 3,4,6-Tri- $O$ - acetyl-2-azido-1- $O$-(4-bromobenzoyl)-2-deoxy- $\alpha$-D- glucopyranoside (19).}

To a solution of compound $8(55 \mathrm{mg}, 0.15 \mathrm{mmol})$ in $\mathrm{CH}_{2} \mathrm{Cl}_{2}(1.5 \mathrm{~mL})$ under nitrogen at $0{ }^{\circ} \mathrm{C}$, morpholine $(52.8$ $\mathrm{ml}, 4$ equiv) was added and the reaction reflux for $2 \mathrm{~h}$ (TLC). The mixture was then diluted with $\mathrm{CH}_{2} \mathrm{Cl}_{2}$ and a solution of $10 \% \mathrm{HCl}$ added. Then, the mixture was extracted with $\mathrm{CH}_{2} \mathrm{Cl}_{2}$, dried, and evaporated in vacuum. The residue $(58 \mathrm{mg}, 0.18 \mathrm{mmol})$ in dry pyridine $(1.8 \mathrm{~mL}$, $10 \mathrm{~mL} / \mathrm{mmol}$ ) was treated with $p$-bromobenzoyl chloride $(57.2 \mathrm{mg}, 1.5 \mathrm{eq})$ and DMAP as catalyst. The reaction was stirred at RT until completion (TLC). Then, it was diluted with $\mathrm{CH}_{2} \mathrm{Cl}_{2}$ and extracted twice with a $10 \%$ solution of $\mathrm{HCl}$, saturated $\mathrm{NaHCO}_{3}$ solution and then with water. The organic layer was dried over $\mathrm{Na}_{2} \mathrm{SO}_{4}$, and evaporated in vacuum. The residue was chromatographed on flash silica gel using $n$-hexane/EtOAc, 85:15. (56.1 mg, 73\% yield), $(\alpha: \beta=1: 1.5)$.

Compound 18 (beta anomer). TLC $\mathrm{R}_{f}=0.38$ ( $n$ hexane/EtOAc, 7:3); $[\alpha]_{\mathrm{D}}$ : $-51.8\left(\mathrm{c} 0.2, \mathrm{CHCl}_{3}\right) ;{ }^{1} \mathrm{H}$ NMR $\left(500 \mathrm{MHz}, \mathrm{CDCl}_{3}\right) \delta 7.95(\mathrm{~d}, J=8.4 \mathrm{~Hz}, 2 \mathrm{H}), 7.63(\mathrm{~d}, J=$ $8.4 \mathrm{~Hz}, 2 \mathrm{H}), 5.78(\mathrm{~d}, J=8.6 \mathrm{~Hz}, \mathrm{H}-1), 5.16(\mathrm{dd}, J=9.5$ and $9.7 \mathrm{~Hz}, \mathrm{H}-3), 5.11$ (dd, $J=9.6$ and $9.4 \mathrm{~Hz}, \mathrm{H}-4), 4.34$ (dd, $J=4.4$ and $12.6 \mathrm{~Hz}, \mathrm{H}-6), 4.11(\mathrm{~m}, \mathrm{H}-6), 3.90$ (m, $\mathrm{H}-5), 3.85$ (dd, $J=9.4$ and $9.0 \mathrm{~Hz}, \mathrm{H}-2), 2.12$ (s, 3H), 2.07 (s, 3H), $2.04(\mathrm{~s}, 3 \mathrm{H}) ;{ }^{13} \mathrm{C} \mathrm{NMR}\left(125 \mathrm{MHz}, \mathrm{CDCl}_{3}\right) \delta 170.5$ (s), $169.7(\mathrm{~s}), 169.6(\mathrm{~s}), 163.6(\mathrm{~s}), 132.1(\mathrm{~d}, 2 \mathrm{C}), 131.6(\mathrm{~d}$, 2C), 129.4 (s), 127.3 (s), 93.4 (d, C-1), 72.9 (d, C-5), 72.7 (d, C-3), 67.8 (d, C-4), 62.9 (d, C-2), 61.4 (t, C-6), 20.6 (q, 2C), 20.5 (q); MS (EI) $\mathrm{m} / \mathrm{z}$ (rel. intensity) 314.0 ( $\mathrm{M}^{+}-\mathrm{OBrBz}, 0.1$ ), 184.9 (98), 182.9 (100); Anal. calcd. for $\mathrm{C}_{19} \mathrm{H}_{20} \mathrm{BrN}_{3} \mathrm{O}_{9}$ : C, 44.37; H, 3.92; N, 8.17, found $\mathrm{C}$, 44.42; $\mathrm{H}, 4.186 ; \mathrm{N}, 8.436$.

Compound 19 (alpha anomer). TLC $\mathrm{R}_{f}=0.38$ ( $n$ hexane/EtOAc, 7:3); $[\alpha]_{\mathrm{D}}$ : $+111.9\left(\mathrm{c} 0.2, \mathrm{CHCl}_{3}\right) ;{ }^{1} \mathrm{H} \mathrm{NMR}$ $\left(500 \mathrm{MHz}, \mathrm{CDCl}_{3}\right) \delta 7.95(\mathrm{~d}, J=8.4 \mathrm{~Hz}, 2 \mathrm{H}), 7.66(\mathrm{~d}, J=$ $8.4 \mathrm{~Hz}, 2 \mathrm{H}), 6.52(\mathrm{~d}, J=3.5 \mathrm{~Hz}, \mathrm{H}-1), 5.56(\mathrm{dd}, J=10.0$ and $9.9 \mathrm{~Hz}, \mathrm{H}-3), 5.18(\mathrm{dd}, J=9.9$ and $9.7 \mathrm{~Hz}, \mathrm{H}-4), 4.31$ (dd, $J=3.8$ and $12.6 \mathrm{~Hz}, \mathrm{H}-6), 4.14(\mathrm{~m}, \mathrm{H}-5), 4.06$ (m, H-6'), 3.83 (dd, $J=3.6$ and $10.6 \mathrm{~Hz} \mathrm{H}-2), 2.14$ (s, 3H), $2.07(\mathrm{~s}, 6 \mathrm{H}) ;{ }^{13} \mathrm{C} \mathrm{NMR}\left(125 \mathrm{MHz}, \mathrm{CDCl}_{3}\right) \delta 170.4(\mathrm{~s})$, 170.0 (s), 169.5 (s), 163.5 (s), 132.2 (d, 2C), 131.5 (d, 2C), 129.4 (s), 127.5 (s), 90.8 (d, C-1), 71.0 (d, C-3), 70.1 (d, C-5), 67.9 (d, C-4), 61.3 (t, C-6), 60.7 (d, C-2), 20.7 (q), 20.6 (q), 20.5 (q); MS (EI) $\mathrm{m} / \mathrm{z}$ (rel. intensity) 314.0 ( $\mathrm{M}^{+}-\mathrm{OBrBz}, 0.1$ ), 184.9 (98), 182.9 (100); Anal. calcd. for $\mathrm{C}_{19} \mathrm{H}_{20} \mathrm{BrN}_{3} \mathrm{O}_{9}$ : C, 44.37; H, 3.92; N, 8.17, found $\mathrm{C}, 44.59$; $\mathrm{H}, 4.264 ; \mathrm{N}, 8.475$.

\subsection{3,4,6-Tri- $O$-acetyl-1-O-(4-bromobenzoyl)-2-[4-(4- bromophenyl)-1H-1,2,3-triazol-1-yl]-2-deoxy- $\beta$-D- glucopyranoside (20f).}

The compound 18 (31 mg, $0.06 \mathrm{mmol})$ and 1-bromo-4ethynyl benzene $(13 \mathrm{mg}, 0.07 \mathrm{mmol})$ were allowed to react following Procedure $\mathrm{C}$ to give compound $20 \mathrm{f}$ (37.4 mg, $90 \%$ yield). TLC $\mathrm{R}_{f}=0.38$ (n-hexane/EtOAc,7:3); mp 221-223 ${ }^{\circ} \mathrm{C}$, dec.; $[\alpha]_{\mathrm{D}}:-53.7$ (c $\left.0.1, \mathrm{CHCl}_{3}\right)$; ${ }^{1} \mathrm{H}$ NMR $\left(500 \mathrm{MHz}, \mathrm{CDCl}_{3}\right) \delta 7.84(\mathrm{~s}, 1 \mathrm{H}), 7.77(\mathrm{~d}, J=7.7 \mathrm{~Hz}, 2 \mathrm{H})$, $7.63(\mathrm{~d}, J=7.6 \mathrm{~Hz}, 2 \mathrm{H}), 7.52(\mathrm{~m}, 4 \mathrm{H}), 6.42(\mathrm{~d}, J=8.7 \mathrm{~Hz}$, $\mathrm{H}-1), 5.89(\mathrm{dd}, J=9.8$ and $10.1 \mathrm{~Hz}, \mathrm{H}-3), 5.31(\mathrm{dd}, J=9.5$ and $9.6 \mathrm{~Hz}, \mathrm{H}-4), 4.98$ (dd, $J=9.6$ and $9.9 \mathrm{~Hz}, \mathrm{H}-2), 4.43$ (dd, $J=4.0$ and $12.4 \mathrm{~Hz}, \mathrm{H}-6), 4.18$ (m, H-6' and $\mathrm{H}-5)$, 2.11 (s, 3H), 2.07 (s, 3H), 1.89 (s, 3H); ${ }^{13} \mathrm{C}$ NMR (125 $\left.\mathrm{MHz}, \mathrm{CDCl}_{3}\right) \delta 170.5(\mathrm{~s}), 169.5(\mathrm{~s}), 169.2(\mathrm{~s}), 163.2(\mathrm{~s})$, 147.1 (s), 132.0 (d, 4C), 131.5 (d, 2C), 129.5 (s), 128.8 (s), 127.3 (d, 2C), 126.9 (s), 122.5 (s), 119.1 (d), 92.3 (d, C-1), 73.2 (d, C-5), 72.0 (d, C-3), 68.1 (d, C-4), 62.9 (d, C-2), 61.4 (t, C-6), 20.6 (q), 20.5 (q), 20.2 (q); MS (EI) m/z (rel. 
intensity) 697:695:693 ([M+1] $\left.]^{+}, 4: 8: 4\right), 184.9(97), 182.9$ (100); Anal. calcd. for $\mathrm{C}_{27} \mathrm{H}_{25} \mathrm{Br}_{2} \mathrm{~N}_{3} \mathrm{O}_{9}$ : C, 46.64; H, 3.62; $\mathrm{N}, 6.04$, found $\mathrm{C}, 46.65 ; \mathrm{H}, 3.92 ; \mathrm{N}, 6.20 ; \mathrm{UV}\left(\mathrm{CH}_{3} \mathrm{CN}\right)$ $\lambda_{\max }(\varepsilon): 250 \mathrm{~nm}(45000) ; \mathrm{CD}\left(\mathrm{CH}_{3} \mathrm{CN}\right) \lambda_{\text {ext }}(\Delta \varepsilon): 258$ (-21.5), $240 \mathrm{~nm}(+12.0)$.

4.41. 3,4,6-Tri-O-acetyl-1-O-(4-bromobenzoyl)-2-[4-(4bromophenyl)-1H-1,2,3-triazol-1-yl]-2-deoxy- $\alpha$-Dglucopyranoside (21f).

Prepared from compound 19 (17 $\mathrm{mg}, 0.033 \mathrm{mmol})$ and 1bromo-4-ethynyl benzene $(7.2 \mathrm{mg}, 0.04 \mathrm{mmol})$ following Procedure C. Compound 21f was obtained in $87 \%$ yield (19.9 mg). TLC $\mathrm{R}_{f}=0.38$ ( $n$-hexane/EtOAc, 7:3); mp 268$270{ }^{\circ} \mathrm{C}$ dec; $[\alpha]_{\mathrm{D}}:+169.0$ (c $0.1, \mathrm{CHCl}_{3}$ ); ${ }^{1} \mathrm{H}$ NMR $(500$ $\left.\mathrm{MHz}, \mathrm{CDCl}_{3}\right) \delta 7.90(\mathrm{~d}, J=8.3 \mathrm{~Hz}, 2 \mathrm{H}), 7.79$ (s, 1H), 7.66 $(\mathrm{d}, J=8.3 \mathrm{~Hz}, 2 \mathrm{H}), 7.49(\mathrm{~m}, 4 \mathrm{H}), 6.68(\mathrm{~d}, J=3.3 \mathrm{~Hz}$, $\mathrm{H}-1), 6.17(\mathrm{dd}, J=9.9$ and $10.7 \mathrm{~Hz}, \mathrm{H}-3), 5.36(\mathrm{dd}, J=9.8$ and $9.7 \mathrm{~Hz}, \mathrm{H}-4), 5.30$ (dd, $J=3.4$ and $11.3 \mathrm{~Hz}, \mathrm{H}-2)$, $4.39(\mathrm{dd}, J=3.8$ and $12.6 \mathrm{~Hz}, \mathrm{H}-6), 4.32(\mathrm{~m}, \mathrm{H}-5), 4.15$ (m, H-6'), $2.17(\mathrm{~s}, 3 \mathrm{H}), 2.11(\mathrm{~s}, 3 \mathrm{H}), 2.10(\mathrm{~s}, 3 \mathrm{H}) ;{ }^{13} \mathrm{C}$ NMR (125 MHz, $\left.\mathrm{CDCl}_{3}\right) \delta 170.5$ (s), 170.0 (s), 169.3 (s), 162.9 (s), 147.1 (s), 132.4 (d, 2C), 132.0 (d, 2C), 131.3 (d, 2C), $129.8(\mathrm{~s}), 128.8(\mathrm{~s}), 127.2(\mathrm{~d}, 2 \mathrm{C}), 127.0(\mathrm{~s}), 122.5(\mathrm{~s})$, 118.6 (d), 90.8 (d, C-1), 70.2 (d, C-5), 68.8 (d, C-3), 68.3 (d, C-4), 61.4 (t, C-6), 61.2 (d, C-2), 20.6 (q), 20.5 (q), 20.4 (q); MS (EI) m/z (rel. intensity) 697:695:693 ([M+1] ${ }^{+}$, 4:8:4), 184.9 (97), 182.9 (100). Anal. calcd. for $\mathrm{C}_{27} \mathrm{H}_{25} \mathrm{Br}_{2} \mathrm{~N}_{3} \mathrm{O}_{9}$ : C, 46.64; H, 3.62; N, 6.04, found $\mathrm{C}$, 47.08; $\mathrm{H}, 4.10 ; \mathrm{N}, 5.68$; UV $\left(\mathrm{CH}_{3} \mathrm{CN}\right) \lambda_{\max }(\varepsilon): 250 \mathrm{~nm}(45000)$; $\mathrm{CD}\left(\mathrm{CH}_{3} \mathrm{CN}\right) \lambda_{\text {ext }}(\Delta \varepsilon): 258(+30.9), 239 \mathrm{~nm}(-11.4)$.

\section{Acknowledgements}

This research was supported by the Vicerrectorado de Investigación e Internacionalización of the Universidad de La Laguna, grant Al CEI10/00018, and the Spanish MINECO, cofinanced by the European Regional Development Fund (ERDF) CTQ2014-56362-C2-1-P. The authors thank to Prof. J. A. Palenzuela (Universidad de La Laguna) for his help in the semi-empirical analyses, and to Prof. V. S. Martín for his suggestions.

\section{References and Notes}

1. Rostovtsev, V. V.; Green, L. G.; Fokin, V. V.; Sharpless, K. B. Angew Chem. Int. Ed. 2002, 41, 2596-2599.

2. Tornфe, C. W.; Christensen, C.; Meldal, M. J. Org. Chem. 2002, 67, 3057-3064.

3. a) Tron, G. C.; Pirali, T.; Billington, R. A.; Canonico, P. L.; Sorba, G.; Genazzani, A. A. Med. Res. Rev. 2008, 28, 278308; b) Iha, R. K.; Wooley, K. L.; Nyström, A. M.; Burke, D. J.; Kade, M. J.; Hawker, C. J. Chem. Rev. 2009, 109, 56205686; c) Sumerlin, B. S.; Vogt, A. P. Macromolecules 2010, 43, 1-13; d) Thirumurugan, P.; Matosiuk, D.; Jozwiak, K. Chem. Rev. 2013, 113, 4905-4979; e) Zurro, M.; Asmus, S.; Beckendorf, S.; Mück-Lichtenfeld, C.; Mancheño, O. G. J. Am. Chem. Soc. 2014, 136, 13999-14002; f). Bachl, J.; Mayr, J.; Sayago, F. J.; Cativiela, C.; Díaz, D. D. Chem. Commun. 2015, 51, 5294-5297; g) Hirst, A. R.; Escuder, B.; Miravet, J. F.; Smith, D. K. Angew. Chem. Int. Ed. 2008, 47, 8002-8018.
4. Kolb, H. C.; Finn, M. G.; Sharpless, K. B. Angew. Chem. Int. Ed. 2001, 40, 2004-2021.

5. a) Biological Properties of $1 \mathrm{H}-1,2,3$ - and 2H-1,2,3-Triazoles, da Silva, F. C.; Cardoso, M. F.; Ferreira, P. G.; Ferreira, V. F. in Chemistry of 1,2,3-triazoles (Eds.: Dehaen, W.; Bakulev, V. A.), Top Heterocycl. Chem. 40, Springer-Verlag, Berlin, Heidelberg, 2015, pp. 117-166. b) Zhang, H.-Z.; Wei, J.-J.; Kumar, K. V. Med. Chem. Res. 2015, 24, 182-196.

6. Dedola, S.; Hughes, D. L.; Nepogodiev, S. A.; Rejzek, M.; Field, R. A. Carbohydr. Res. 2010, 345, 1123-1134.

7. a) Bokor, E.; Docsa, T.; Gergely, P.; Somsàk, L. Bioorg. Med. Chem. 2010, 18, 1171-1180; b) Goyard, D.; Docsa, T.; Gergely, P.; Praly, J.-P.; Vidal, S. Carbohydr. Res. 2015, 402, 245-251.

8. a) Chow, H.-F.; Lau, K.-N.; Ke, Z.; Liang, Y.; Lo, C.-M. Chem. Commun. 2010, 46, 3437-3453; b) Schulze, B.; Schubert, U. S. Chem. Soc. Rev. 2014, 43, 2522-2571, and references therein.

9. a) Mangunuru, H. P. R.; Yerabolu, J. R.; Liu, D.; Wang, G. Tetrahedron Lett. 2015, 56, 82-85; b) Babu, S. S.; Praveen, V. K.; Ajayaghosh, A. Chem. Rev. 2014, 114, 1973-2129; c) Terech, P.; Weiss, R. G. Chem. Rev. 1997, 97, 3133-3159; d) Cravotto, G.; Cintas, P. Chem. Soc. Rev. 2009, 38, 26842697.

10. a) Harada, N.; Nakanishi, K. Circular Dichroic Spectroscopy. Exciton Coupling in Organic Stereochemistry, University Science Books: California, 1983; b) Circular Dichroism: Principles and Applications, 2nd Ed., (Eds.: Berova, N.; Nakanishi, K.; Woody, R. W.), Wiley-VCH, New York, N. Y., 2000; c) Lightner, D. A.; Gurst, J. E. Conformational Analysis and Stereochemistry from Circular Dichroism Spectroscopy, Wiley-VCH, New York, N. Y., 2000; d) Pescitelli, G.; Di Bari, L.; Berova, N. Chem. Soc. Rev. 2011, 40, 4603-4625.

11. Tosin, M.; Murphy, P. V. Org. Lett. 2002, 4, 3675-3678.

12. Ibatullin, F. M.; Selivanov, S. I. Tetrahedron Lett. 2002, 43, 9577-9580.

13. Bianchi, A.; Bernardi, A. J. Org. Chem. 2006, 71, 4565-4577.

14. Initial attempts to isolate the anomeric mixture of the ditriazoles 11a-11g and 12a-12g obtained directly from mixture of the diazides $\mathbf{9}$ and $\mathbf{1 0}$ were unsuccessfully. So these diazides must be isolated before the coupling reaction is performed, although separation was hard to achieve.

15. Most 1,2-ditriazoles synthesized in this work showed high polarity and ability for gelation in DMSO. This study is currently underway.

16. Snider, B. B.; Lin, H. Synth. Commun. 1998, 28, 1913-1922.

17. Yan, R.-B.; Yang, F.; Wu, Y.; Zhang, L.-H.; Ye, X.-S. Tetrahedron Lett. 2005, 46, 8993-8995.

18. Pandiakumar, A. K.; Sarma, S. P.; Samuelson, A. G. Tetrahedron Lett. 2014, 55, 2917-2920.

19. Szabo, M.; Agostino, M.; Malone, D. T.; Yuriev, E.; Capuano, B. Bioorg. \& Med. Chem. Lett. 2011, 21, 6782-6787.

20. Wiesler, W. T.; Vázquez, J. T.; Nakanishi, K. J. Am. Chem. Soc. 1987, 109, 5586-5592.

21. Wang, Z.-X.; Qin, H.-L. Chem. Comm. 2003, 2450-2451, and references therein.

22. Hartzel, L. W.; Benson, F. R. J. Am. Chem. Soc. 1954, 76, 667-670.

23. PCModel v. 9.2, Serena Software, Box 3076, Bloomington, IN 47402-3076; and MOPAC2016, James J. P. Stewart, Stewart Computational Chemistry, Colorado Springs, CO, USA. 
24. Wilkinson, B. L.; Bornaghi, L. F.; Poulsen, S.; Houston, T. A. Tetrahedron 2006, 62, 8115-8125.

25. Wilkinson, B. L.; Bornaghi, L. F.; Houston, T. A.; Poulsen, S.-A.; White, A. R. Acta Cryst. 2006, E62, o5065-05067.

26. Cai, G.; Bozhkova, N.; Odingo, J.; Berova, N.; Nakanishi, K. J. Am. Chem. Soc. 1993, 115, 7192-7198.

27. Ogawa, T.; Nakabayashi, S.; Shibata, S. Agric. Biol. Chem. 1983, 47, 281-285.

28. Akula, R. A.; Temelkoff, D. P.; Artis, N. D.; Norris, P. Heterocycles 2004, 63, 2719-2725.

29. Goyard, D.; Chajistamatiou, A. S.; Sotiropoulou, A. I.; Chrysina, E. D.; Praly, J.-P.; Vidal, S. Chem. Eur. J. 2014, 20, 5423-5432.

30. a) Geng, J.; Lindqvist, J.; Mantovani, G.; Chen, G.; Dayers, C. T.; Clarkson, G. J.; Haddleton, D. M. QSAR Comb. Sci. 2007, 26, 1220-1228; b) Persec, V.; et al. J. Am. Chem. Soc. 2013, 135, 9055-9077; c) Kang, B.; Okwieka, P.; Schöttler, S.; Winzen, S.; Langhanki, J.; Mohr, K.; Opatz, T.; Mailänder, V.; Landfester, K.; Wurm, F. R. Angew. Chem. Int. Ed. 2015, 54, 7436-7440.

31. a) Magnus, P.; Lacour, J.; Evans, P. A.; Roe, M. B.; Hulme, C. J. Am. Chem. Soc. 1996, 118, 3406-3418; b) Kamble, D. A.; Karabal, P. U.; Chouthaiwale, P. V.; Sudalai, A. Tetrahedron Lett. 2012, 53, 4195-4198. 